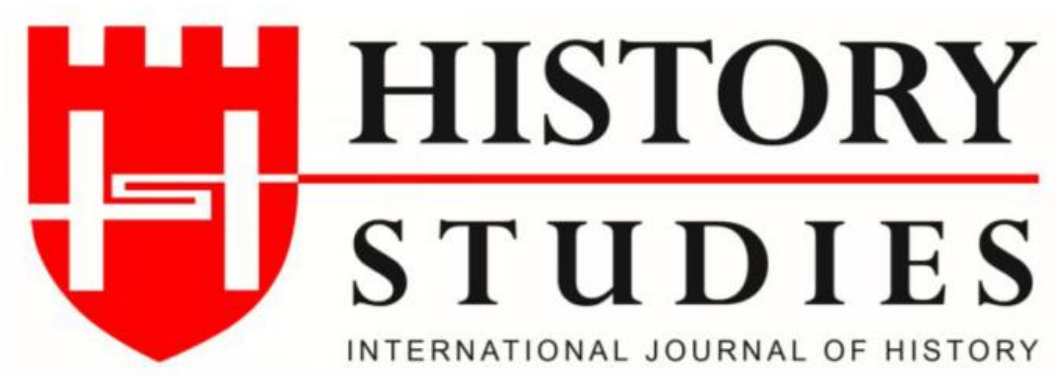

ISSN: 13094173 (Online) 1309 - 4688 (Print)

Volume 12 Issue 5, October 2020

DOI Number: 10.9737/hist.2020.928

Araştırma Makalesi

Makalenin Geliș Tarihi: 31.07.2020 Kabul Tarihi: 27.08.2020

Atıf Künyesi: Mehmet Kutlu, “Orta Asya'da Tütekli (Kırlangıç) Örtünün Kökeni ve Tarihî Gelişim Aşamaları Üzerine bir Değerlendirme", History Studies, 12/5, Ekim 2020, s. 2455-2486.

\title{
Orta Asya'da Tütekli (Kırlangıç) Örtünün Kökeni ve Tarihî Gelişim Aşamaları Üzerine bir Değerlendirme
}

\author{
An Assessment on the Origin of the Lantern Roof and Its Historical Development \\ Stages in Central Asia
}

\author{
Dr. Mehmet Kutlu \\ ORCID No: 0000-0002-3075-3965 \\ Pamukkale Üniversitesi
}

\section{$\ddot{O} \mathbf{z}$}

\begin{abstract}
Ahşap tütekli örtü başta Orta Asya, Sibirya, Kafkasya ve Anadolu coğrafyaları olmak üzere oldukça geniş alanlara yayılmış bir mimari unsurdur. Geleneksel konut mimarisinin yanı sıra anıtsal ve dini mimaride de yaygın kullanımı bulunmaktadır. Şimdiye kadar yapılan çalışmalarda Kuzey Asya kökenli bir uygulama olduğu ve diğer bölgelere Orta Asya üzerinden dağıldığ ifade edilmiş̧ir. Ancak bu görüşün arkeolojik verilerin ışığında ve tarihi süreç içinde kronolojik gelişimi ortaya konulmamıştır. Bu çalışma arkeolojik veriler ışığında kronolojik olarak ahşap tütekli örtüyü ele alarak söz konusu alana katkı sunmayı amaçlamaktadır. Arkeolojik kazılardan elde edilen bilgilere göre bilinen en erken tarihli ahşap tütekli örtü uygulaması, Kuzey Kazakistan'da tespit edilmiştir. Kalkolitik döneme tarihlenen Botay yerleşiminde M.Ö. 3700-3500 yllarına tarihlenen konutların ahşap tütekli örtüye sahip olduğu kanıtlanmıştır. Botay'da M.Ö. 1500 yıllarına kadar aralıksız devam eden yerleşime ait yüzlerce konutta bu örtü uygulanmaya devam edilmiş̧ir. Arkeolojik veriler ışığında Tunç Çağı'ndan itibaren bu örtü uygulamasının Botay'dan batıya Urallar ve Karadeniz'in kuzeyi ile Kafkasya'ya, diğer yönden Altaylar ve Sibirya'nın derinliklerine, güneye doğru ise Orta ve Güney Kazakistan'a, daha sonra oradan, Doğu Türkistan'a, Özbekistan ve Tacikistan'a doğru yayıldığı anlaşılmıştır. Ahşap tütekli örtü, Kazakistan ve Sibirya bölgelerinde yerel mimarinin geleneksel bir unsuru haline gelerek günümüze kadar kültürel sürekliliğin bir göstergesi olarak uygulanmaktadır.
\end{abstract}

Anahtar Kelimeler: Orta Asya, Kazakistan, Sibirya, geleneksel mimari, ahşap tütekli örtü.

\section{Abstract}

The wooden "lantern roof" is an architectural element spread over a wide area, particularly in the Central Asia, Siberia, Caucasus and Anatolia. It has widespread use in monumental and religious as well as vernacular architecture. In the studies carried out so far, it is stated that "lantern roof" is an application originating from the North Asia and distributed to the other regions through Central Asia. However, chronological development of the lantern roof, 
Orta Asya'da Tütekli (Kırlangıç) Örtünün Kökeni ve Tarihî Gelişim Aşamaları Üzerine bir Değerlendirme

has not been addressed within the context of archaeologic data and historical process. The aim of current study is to contribute to the area by discussing the development of wooden lantern roof chronologically in the light of archaeological data. According to the information obtained from archaeological excavations, the earliest known wooden lantern roof was determined in North Kazakhstan. It has been revealed that the pit-houses at the Chalcolithic Botai settlement dated to 3700-3500 BC had lantern roofs. This roof technique had been continuously applied until $1500 \mathrm{BC}$ in more than hundred houses revealed at Botai. Starting from the Bronze Age the lantern roof spread from Botai to the Central, Eastern and Southern Kazakhstan, through the Altai Mountains to the depths of Siberia, in the west to the Ural area, through the Caucasus to the Black Sea region and later through the Eastern and Southern Kazakhstan to the Eastern Turkistan, Uzbekistan and Tajikistan. The lantern roof has become a traditional element of vernacular architecture in Kazakhstan and Siberia regions and has been used as an indicator of cultural continuity until nowadays.

Keywords: Central Asia, Kazakhstan, Siberia, vernacular architecture, lantern roof

\section{Giriş}

Orta Asya Türk Tarihinin erken dönemlerinde geleneksel mimarinin ortaya çıkışı ve hangi gelişim aşamalarından geçerek şekillendiği konusu hala tam anlamıyla ortaya koyulamamıştır. Bilindiği gibi oldukça geniş coğrafyalarda Proto-Türk ve Türk halklarının varlık göstermesi konunun ele alınmasını zorlaştırmaktadır. Ancak söz konusu geniş coğrafyalarda günümüze kadar birçok arkeolojik kazı çalışmasının yürütülmesi Türk tarihinin erken dönemlerinde uygulanan mimari hakkında bazı bilgi ve bulgulara ulaşılmasını sağlamaktadır. Diğer yandan Orta Asya coğrafyasında yürütülen arkeolojik çalışmalarda genellikle zengin buluntuları nedeniyle mezar anıtlarına (kurgan) öncelik verilmesi nedeniyle özellikle İskitler, Hunlar, Göktürkler başta olmak üzere bozkır halklarına yönelik yerleşim arkeolojisi daha az rağbet görmektedir. $\mathrm{Bu}$ çalışma öncelikle arkeolojik veriler 1şı̆̆ında bilinen ilk örnekleri günümüz Kazakistan coğrafyasında Kalkolitik Çağa kadar inen ahşap malzemeden inşa edilen tütekli örtü uygulamalarına odaklanmaktadır. Kalkolitik dönemden başlayarak 20. yüzyıla kadar Kazakistan coğrafyası ve çevre bölgelerde geleneksel mimarinin vazgeçilmez bir ögesi olan tütekli örtü örneklerini irdelemektedir.

\section{Tütekli Örtü}

Ülkemizde halk arasında "kırlangıç kubbe" olarak adlandırılan ahşap örtü uygulaması sanat tarihi ve mimarlık tarihi bilim alanlarında "kırlangıç örtü” "tütekli örtü" veya "tüteklikli örtü” ve "bindirme tavan" gibi kavramlarla ifade edilmektedir. Bir sanat tarihi kavramı olarak "kare ya da kareye yakın dikdörtgen planlı bir mekânın üstünü, köşelerden başlayarak birbiri üzerine çapraz konumda oturtulmuş ahşap kalaslardan (bazen işlenmemiş ağaç gövdelerinden) oluşan bir sistemle örten bir bindirme kubbe türü" şeklinde tanımı yapılmaktadır. ${ }^{1}$

"Tütekli örtü" için Almanca "laternendecke" ve İngilizce "lantern roof" veya "swallow dome" terimleri kullanılırken Kazakistan'da "karatam", Azerbaycan'da "garadam", İran'da "darvaze", Gürcistan'da "darbazi”, Ermenistan'da "hazaraashen", Tacikistan'da "rusan" olarak adlandırılmaktadır. ${ }^{3}$ Birbirine oldukça yakın Gürcistan ve Ermenistan'da Farsça kökenli iki farklı terim kullanılırken, aralarında oldukça uzun mesafe olmasına rağmen Kazakistan'ın orta ve doğu bölgeleri ile Azerbaycan'da aynı terimin kullanılması da önemli bir husus olarak dikkat

\footnotetext{
${ }^{1}$ Metin Sözen- Uğur Tanyeli, Sanat Kavram ve Terimleri Sözlüğ̈̈, Remzi Kitabevi, İstanbul, 2003,s. 243.

${ }^{2}$ Alkey Margulan, Sigarmalart, Alatau Bastası Almatı, 2010, Cilt 9, s. 184.

${ }^{3}$ Sunah Choi, "Bindirme Tavan": Bir Adlandırma Sorunsalı" Ankara Üniversitesi Sosyal Bilimler Dergisi, 8(2), 2017, s. $195-200$.
} 
çekmektedir. Kazak topluluklarında genellikle kışlaklarda inşa edilen ahşap tütekli örtüye sahip dairesel planlı evlere, "karatam", "şoşala" ve "moroşak" 4, Sibirya bölgesindeki Altay Türklerinde ise "çer uyg" (yer ev) ${ }^{5}$, Hakas Türklerinde ib (ev) veya agas ib (ağaç ev) ve Şor Türklerinde ise ail (ağıl) denmektedir. ${ }^{6}$

"Kırlangıç örtü" ve "kırlangıç kubbe" kavramları halk arasında yaygın olmasına rağmen araştırma konumuz olan tütekli ahşap örtüyü tam olarak karşılayan bir anlam bağına sahip değildir. Diğer kavramlardan "bindirme tavan" ahşap örtünün "bindirme" tekniğiyle inşa edilmesi nedeniyle önerilmektedir ancak ahşap örtünün duman tahliyesi ile mekânın havalandırılması ve aydınlatmasına yönelik işlevlerini dikkate almamaktadır. Sanat Tarihi'nde bir kavram olarak "tüteklik" ise Türk hamamlarında 1sitma sisteminin ve duman tahliyesinin bir unsuru olarak özel bir anlama kavuşmuştur. Ancak bu çalışmanın konusu olan ahşap örtüyle ilgisini kurmak güçtür. Ahşap örtünün duman tahliyesinin yanı sıra mekânın havalandırılması ve aydınlatmasına yönelik işlevlerinin de olması nedeniyle "tütekli örtü" olarak tanımlanması daha uygun bulunmaktadır.

Ülkemizde tütekli örtü üzerine en kapsamlı çalışmaları, Günkut Akın yapmıştır. ${ }^{7}$ Önce “tüteklikli örtü” kavramını tanımlamış, kökeni ve en erken örneklerini ele almaya çalışmış, konutlarda veya anıtsal mimarideki örnekler hakkında bilgi vermiş daha sonra Anadolu'da cami ve tarikat yapılarında görülen tütekli örtü örneklerini detaylı incelemiştir. Diğer bir çalışma ise Sunah Choi'nin "bindirme tavan" kavramı bağlamında konuyu ele alan doğru terimin belirlemesine ve kullanılmasına dikkat çeken makalesidir. ${ }^{8}$ Ahşap örtünün inşasında kullanılan "bindirme" tekniğinden hareketle tüteklikli örtü veya kırlangıç kubbe yerine "bindirme tavan" teriminin kullanılmasını önermektedir. Ayrıca, "tütekli örtü" kavramının karşılığ1 olarak Ortadoğu yanı sıra Çin, Japon, Kore gibi Uzakdoğu ülkelerinde kullanılan terimleri de ele almıştır. Tütekli örtünün kökeni ve gelişimi konusunda detaylı olmasa da önemli bilgileri ortaya koyan diğer bir çalışma ise Zerrin Köşklü ve Şerife Tali'nin makalesidir. ${ }^{9}$ Erzurum evlerindeki tandırevi ve mimarisine yönelik bu çalışmada, ahşap tütekli örtüye sahip olan tandır evlerinin kökeninin başta Orta Asya olmak üzere oldukça geniş coğrafyada görülen ve Neolitik döneme kadar inen yerevi (çukur ev) olduğu belirtilmiştir. Ayrıca Orta Asya'da yaşayan Proto-Türk ve Türk halkların konutlarında ahşap tütekli örtünün bulunduğu ifade edilmiştir.

\footnotetext{
${ }^{4}$ Margulan, 2010, age, s. 184.

${ }^{5}$ Leonid Potapov, Oçerki po istorii Altaytsev, OGİ, Novosibirsk, 1948, s. 38.

6 İgor Kızlasov, Pratyurkskiye jilişa. Obsledovaniye Sayano-Altayskih drevnostey, Moskva-Samara, 2005,, s. 33-36.

${ }^{7}$ Günkut Akın, "Tütekli Örtü Geleneği Anadolu Cami ve Tarikat Yapılarında Tüteklikli Örtü”, Vakıflar Dergisi, 22, İstanbul, 1991, s. 323354.

${ }^{8}$ Sunah Choi, agm, s. 195-202.

${ }^{9}$ Zerrin Köşklü-Şerife Tali, “Geleneksel Erzurum Evlerinde Tandırevi (Mutfak) ve Mimarisi” Sanat Dergisi 11, 2007 s. $97-111$.
} 

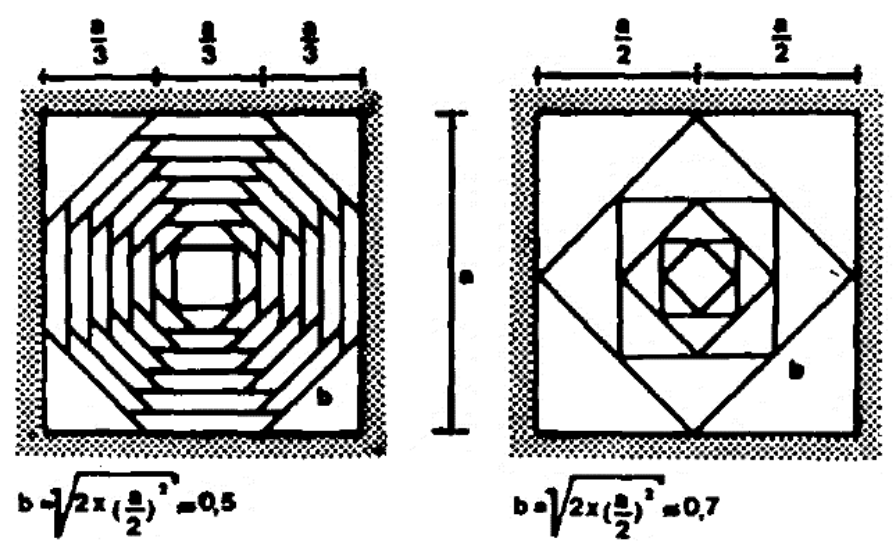

Çizim 1: Tütekli örtü tipleri (sekizgen ve kare) ve geometrisi (G. Akın, 1991, s. 348)

Bununla birlikte Kuzey ve Kuzeydoğu Anadolu'da özellikle geleneksel konut mimarisinde çok sayıda örneği bulunan tütekli (kırlangıç) örtü geleneği zaman zaman bazı camilerin örtü sisteminde de uygulanmıştır. ${ }^{10}$ Günkut Akın'ın belirttiği gibi bu örtü tekniğinin kökeni üzerine birçok yabancı araştırmacının da ulaştığı sonuç tütekli örtünün soğuk iklim özellikleri gösteren Orta Asya'nın kuzey bölgelerinde ortaya çıkmış olabileceği şeklindedir. ${ }^{11}$

\section{1. Orta Asya'da Tütekli Örtü}

Orta Asya'da yürütülen arkeolojik araştırmalar sonucunda geleneksel mimarinin ortaya çıkışı ve gelişimine dair bazı önemli bilgilere ulaşılmıştır. Bu noktada en dikkat çeken unsurlardan biri de ahşap tütekli örtü uygulamaları olmuştur. Örneğin, son dönemlerde Kazakistan'ın kuzey bölgelerinde özellikle Botay'da yürütülen arkeolojik kazılarda ahşap malzemeden inşa edilmiş tütekli (kırlangıç) örtünün bilinen en eski tarihli örnekleri tespit edilmiştir. Botay'da dairesel veya çokgen planlı konutların örtüsünün yukarı doğru daralan ağaç tomruk veya kalaslardan inşa edildiği kanıtlanmıştır. Bakır Taş Çağı'na (Kalkolitik) tarihlenen ahşap tütekli konutlarıyla Botay, aynı zamanda atın ilk evcilleştirildiği kültür olarak bilinmektedir. ${ }^{12}$

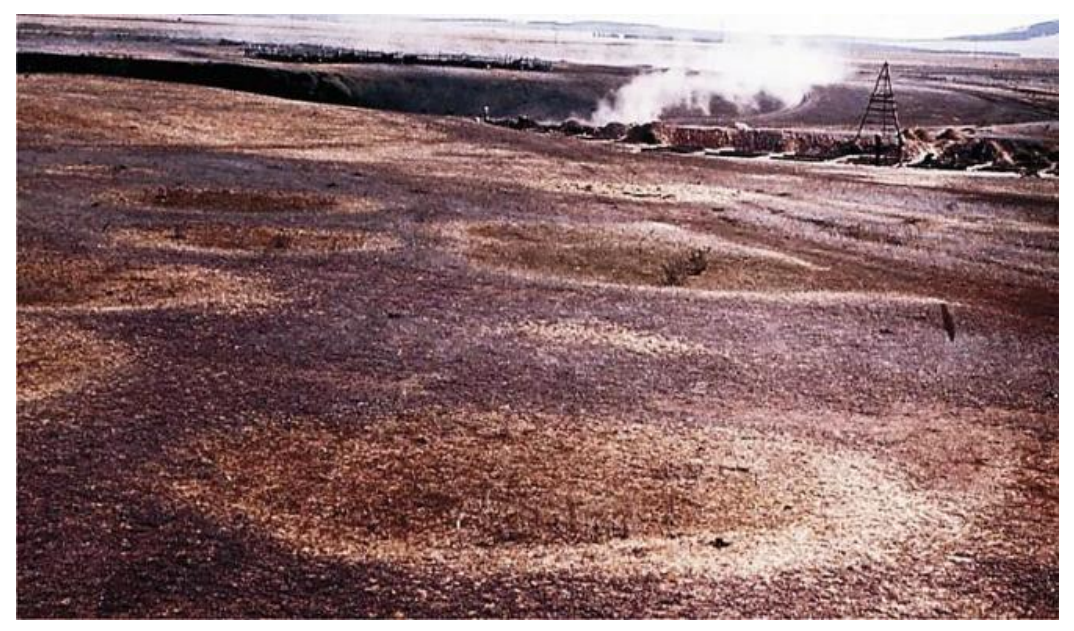

Fotoğraf 1: Kazı öncesi Botay yerleşimi, (Zaibert, 2009, s. 176-177).

\footnotetext{
${ }^{10}$ Akın, agm, s. 331-336.

11 agm, s. 325.

12 Viktor Zaibert Eneolit Uralo-İrtısskogo mejdurechya, Pertopavlovsk, Nauka, Kazahstan, 1993, s. 20-21.
} 
1980 yılında başlatılan arkeolojik araştırmalar sonucunda keşfedilen Botay prehistorik yerleşimi, Kazakistan'ın kuzeyinde Kökşetau vilayetinin Ayırtau ilçesine bağlı Saumalköl köyünün $1,5 \mathrm{~km}$ güneydoğusunda konumlanmaktadır. M.Ö. 4. bin yıla kadar inen kültür katmanlarına sahip olan Botay, Esil (İşim) nehrinin bir kolu olan İmanburlık Çayı'nın sağ yakasında, yaklaşık 15 hektarlık alana yayılmıştır. Yerleşimin bir ucu çam ve huş ağaçlarından meydana gelen yoğun ve sık bir ormana, diğer ucu ise nehir yatağındaki oldukça büyük ve derin bir yar veya uçuruma doğru uzanmaktadır. Ormana yakın olması nedeniyle Botay'da yoğun ahşap malzemeye dayalı bir mimari oluşumu gözlenmektedir. ${ }^{13}$

1983 yılında materyal kültür bağlamında Botay ile ortak özellikler gösteren Roşinskoye yerleşimi keşfedilmiştir ${ }^{14}$. Daha sonraki yıllarda ise Tobol- Esil nehirleri arasındaki bölgede yine Botay ile benzer arkeolojik buluntulara sahip diğer bazı prehistorik yerleşimler tespit edilmiş ve Botay kültürü kapsamında değerlendirilmiştir. Söz konusu yerleşim yerlerinin başlıcaları Kızıl Yar, Balandino, Kenötkel ve Selenti'dir. Botay kültürünün erken dönemine ait katmanlar M.Ö. 3700-3100 yılları arasına tarihlenmektedir. Kazak ve İngiliz araştırmacılardan oluşan bir bilim ekibi bu döneme ait katmanlarda bulunan at kemiklerinden alınan numuneleri Oxford Üniversitesi laboratuvarlarında radyo-karbon testine tabi tutmuş ve yaklaşık olarak M.Ö. 3500 yılına tarihlemiştir ${ }^{15}$. Ayrıca bu döneme ait katmanlarda ele geçen bazı keramik kaplarda kısrak sütünün fermentasyonuyla yapılmış kımız kalıntıları da tespit edilmiştir. ${ }^{16}$

Botay'daki yerleşiminin en geç evresi ise M.Ö. 16. yüzyıla kadar sürmüştür. Botay'da yürütülen çalışmalarda sayıları 158'i bulan konutun kazısı gerçekleştirilmiş ve bu konutlarının büyük çoğunluğunun geç evrelere yani Tunç Çağına ait olduğu anlaşılmıştır. ${ }^{17}$ Botay'da kazılar sonucu ortaya çıkarılan ve Kalkolitik döneme tarihlenen 15 no'lu yapı Botay kültürünün erken dönemlerine (M.Ö. 3500) ait mimari özellikleri oldukça iyi yansıtmaktadır. Bu evreye veya döneme ait yapıların kazı öncesinde dairesel planlı oldukları, 3-6 m arasında değişen çapta oldukları ve etraflarında yaklaşık 10-20 cm derinliğe sahip hendekler bulunduğu görülmüştür (Foto. 1). Kazılar sonucunda Kalkolitik döneme ait Botay konutların aşağıda listelenen tabakalara sahip olduğu saptanmıştır: En dipte ana toprak veya ana kaya tabakası bulunmaktadır. İkinci tabaka ise yapının mimari öğelerine ait temel kalıntıları ve yapının kullanıldığı döneme ait odun, kömür, kül, çöp ve iş aletleri kalıntıları ile bütün veya parçalanmış haldeki keramik buluntularına rastlanmıştır. Üçüncü tabakada yapıların örtü, duvar, sıva, hendek, giriş dehlizleri gibi mimari unsurlarına ait kalıntılar; en üst tabakada ise yapıların yıkılması sonrasında oluşan toprak tabakası bulunmaktadır. ${ }^{18}$

Kazı çalışmalarında Botay konutlarının nasıl inşa edildiğine dair önemli bilgilere ulaşılmıştır. Prof. Dr. Viktor Zaibert'e göre genişlikleri 30-70 m2 arasında değişen Botay konutlarının inşası için öncelikle zemin $0,60-0,80 \mathrm{~m}$ derinliğe kadar kazılarak dairesel planlı veya köşeleri yuvarlatılmış çokgen planlı bir çukur oluşturulmaktadır. Daha sonra çukurdan çıkarılmış ve ıslatılmış toprak kesekleriyle duvarlar örülmektedir. Duvarları güçlendirmek amacıyla hem iç hem de dış cephelerde çeşitli hayvan kemikleri kullanılmıştır. Sıkıştırılmış topraktan inşa edilen

\footnotetext{
${ }^{13}$ Viktor Zaibert, Botayskaya kultura, Almat1: "KazAkparat”, 2009, s. 237.

${ }^{14}$ A. Kislenko, Raskopki Poseleniya Roşinskoye, Nauka, Moskva, 1984. s. 511.

${ }^{15}$ A.K. Outram, N.A. Stear, R. Bendrey, S. Olsen, A. Kasparov, Viktor Zaibert, Thorpe N., Evershed R.P. "The earliest horse harnessing and milking", Science, Cilt 323, Say1 5919, 2009, s. 1334.

${ }^{16}$ agm, s. 1334.

${ }^{17}$ L. Dzhansugurova, Viktor Zaibert, E. Kitov, O. Ixan, Nurzhibek, G. Zhunussova, K. Dzhantaeva, E. Kuzovleva, E. Khussainova, "Paleogenetic Investigation of the Human Remains of the Eneolithic Period from the settlement Botai", News of the National Academy of Sciences of the Republic of Kazakhstan, Cilt 4, Say1 322, 2017, s. 78-79.

${ }^{18}$ Zaibert, 1993, age, s. 20-21.
} 
duvarların kalınlıkları 0,80-1,20 m. yükseklikleri ise 0,60-1,00 cm. arasında değişmektedir. ${ }^{19}$ Duvarlar ve zeminin sıvasında kaolin kiline sahip topraklar kullanılmıştır. Bu toprak malzemenin itinayla seçildiği hatta farklı yerlerden getirildiği de tespit edilmiştir. Topraktan inşa edilen duvarların üzerine ahşap malzeme ile tavanın kirişleri yerleştirilmiş ve örtü sistemi kırlangıç örtü tekniğine göre kademeli olarak daraltılarak ortada kare kesitli bir açıklık bulunacak şekilde tamamlanmıştır. Örtü sisteminde kullanılan tomrukların arasındaki boşluklar önce toprakla sıvanmış sonra huş ağacı kabukları veya çimli toprak keseklerle örtülerek 1sı ve nem yalıtımı yapılmıştır. ${ }^{20}$ Yapının içten yüksekliği tabandan tavana yapılan araştırmalara göre 2,70-3,50 m arasında değişebileceği anlaşılmıştır²1 .

Bu tür konutlara ülkemiz arkeoloji literatüründe "çukur barınak", İngilizce literatürde "pithouse" veya "earth lodge" denilmektedir. Bu konut türü Neolitik ve Kalkolitik dönemlerde birçok coğrafyada görülmesine rağmen çukur barınakların tamamının ahşap tütekli örtüye sahip olduğu söylenemez. Ahşap tütekli örtü ise oldukça özel bir uygulamadır ve özellikle yalıtım ihtiyacının fazla olduğu soğuk iklim kuşağında ortaya çıktığı düşünülmektedir. Günümüzde dahi ahşap tütekli örtünün Orta Asya'nın kuzeyi, Sibirya, Kafkasya ve Kuzeydoğu Anadolu'nun soğuk bölgelerinde kullanılmaya devam edilmesi buna kanıt olarak söylenebilir.

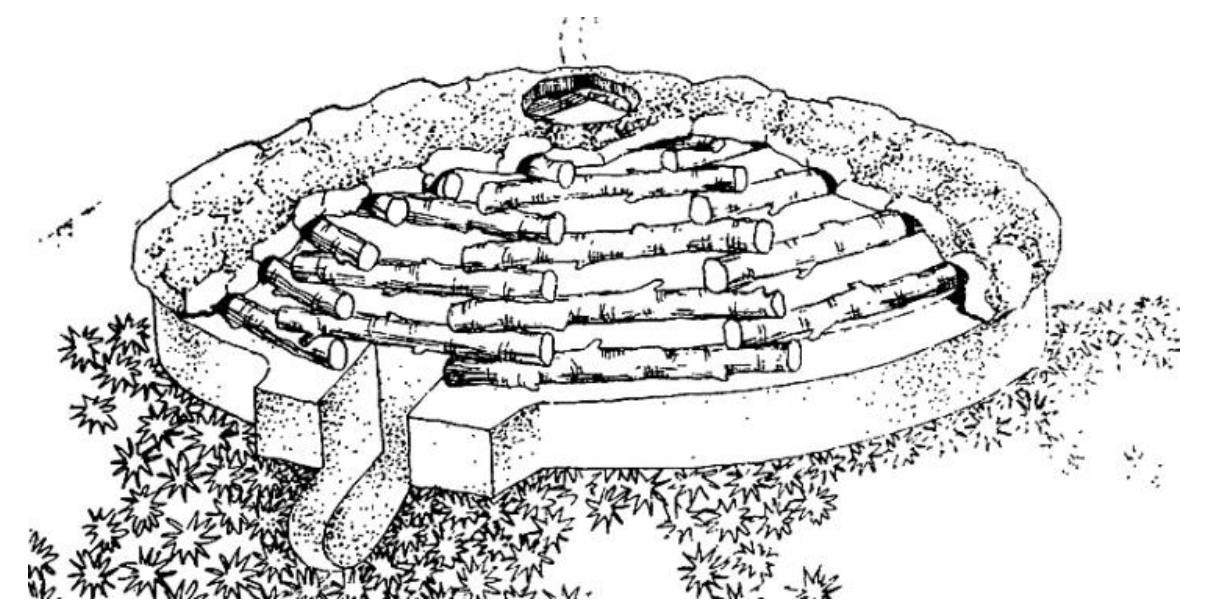

Çizim 2: Botay konutunun restitüsyonu. (A. Kislenko, 1993, s.131)

Botay konutlarının rekonstrüksiyon çalışmaları Prof. Dr. Viktor Zaibert başkanlığında A.M. Kislenko ve ekibi tarafından gerçekleştirilmiştir. Öncelikle konutların teorik restitüsyon modeli oluşturulmuş daha sonra bu plan uygulamalı deneylerle test edilmiştir. Birkaç yıl dört mevsim boyunca takibi gerçekleştirilen uygulamalı deneyler sonucunda ulaşılan bilgilerden hareketle teorik restitüsyon planı revize edilerek son şeklini almış ve böylece konutların rekonstrüksiyonu çalışmalarına başlanmıştır (Çiz. 2, Res. 1, Foto. 3).

1983 yılında Kuzey Kazakistan Arkeolojik Ekspedisyonu ekibi tarafindan Botay konutlarının daha iyi anlaşılabilmesi amacıyla uygulamalı deneylerle inşa süreci değerlendirilmiştir. 14-15 yaşlarındaki 15 gençten oluşan bir ekip oluşturulmuş ve 2 haftalık süre içerisinde gerçek boyutlu bir Botay konutu inşa edilmiştir (Foto. 2, 3). Öncelikle konut için bir çukur kazılmış, sonra çukurun çevresi boyunca zemin seviyesine kadar toprak malzeme kullanılarak yaklaşık 1,00 m kalınlığa ve 0,70-75 m yüksekliğe sahip duvar örülmüştür. Başlangıçta duvar inşasında çukurdan çıkarılan toprak, malzeme olarak kullanılmış, sonra yerleşimin çeşitli bölgelerinde bolca bulunan

\footnotetext{
${ }^{19}$ age, s. $20-21$.

${ }^{20}$ age, s. $20-21$.

${ }^{21}$ L. Dzhansugurova vd., 2017, s.79.
} 
kaolin kili içeren toprak malzeme kullanılmıştır. Kazı çalışmalarında söz konusu kaolin kilinin Botay'da konut inşasında kullanıldığını kanıtlayan çok sayıda çukur kazıldığı tespit edilmiştir. Daha sonra duvarın üzerine çapları $0,13-0,20 \mathrm{~m}$. arasında değişen ve yaklaşık 4-5 metre uzunluğa sahip ahşap tomruklar kullanılarak örtü inşa edilmiştir. Toprak malzemeden inşa edilen duvarının genişliği tomrukların dışa taşmadan dizilmesine olanak sağlamıştır. Sekiz sıra halinde üst üste bindirilerek ve yukarıya doğru daraltılarak inşa edilen ahşap örtünün ortasında konutun merkezindeki ocağın dumanını tahliye işlevi gören yaklaşık 0,50x0,50 m. ölçülerinde kare kesitli bir (tütek) açıklık bırakılmıştır. Ahşap örtünün sağlamlığının arttırılması için tomruklar uçlarından derin olmayan çentiklerle (karaboğaz geçme tekniğinde) oyularak birbirine geçmeli inşa edilmiş ve birbirine sabitlenerek tutturulmuştur. Böylece sekiz sıra tomruktan tavana doğru daralan yedi köşeli bir örtü oluşmuştur. Ayrıca yapının merkezinden güney ve kuzey yönde dikilen iki direkle desteklenen ve tek sıra halinde dizilen tomruklardan bir düz ahşap örtü yapılmıştır. Örtünün ise üzerine kalın ağaç dalları ve çim kesekleri serilmiştir. Böylece yapının merkezinde tavan yüksekliği yaklaşı 2,20 metreye ulaşmıştır ${ }^{22}$. Deneysel uygulamalarda konutun ortasında konumlanan ocakta ateş yakılmasıyla tavanın alçak olduğu ve dumanın dışarıya tahliye olmadığı görülmüştür. Ayrıca çapının büyük olmasından dolayı tek sıra halinde dizilen tomruklarla inşa edilen ahşap örtü, iki direkle desteklenmiş olmasına rağmen çok geçmeden yıkılmıştır

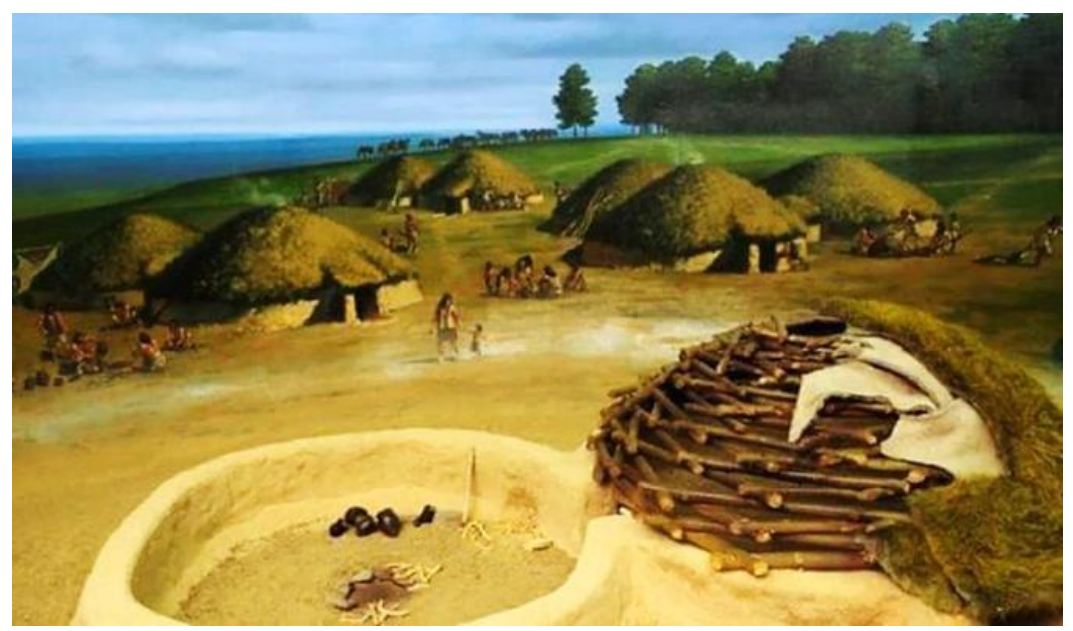

Resim 1: Botay yerleşiminin restitüsyonu, V. Zaibert, 2009, s. 176-177.

1984 y1lında ise uygulamalı deneylerde ahşap örtü tamamen piramidal tütekli (kırlangıç) örtü tekniğine göre inşa edilmiştir. Ahşap örtü $45^{\circ}$ derece eğimli hale getirilmiş, böylece tavan yüksekliği artmış ve ocak dumanının dışarı tahliyesi kolayca sağlanmış, örtü ise direklere ihtiyaç duyulmadan taşınan oldukça sağlam ve dayanaklı bir nitelik kazanmıştır. ${ }^{23}$

Kazılarda yapıların kuzeydoğu kısmındaki beden duvarlarında saptanan düzensizlikler ve bozulmaların varlığı, yapıların giriş veya kapı açıklıklarının kuzeydoğu kısımda konumlandırılmış olabileceğini göstermektedir. Böylece inşa edilen konut modelinin kuzeydoğu kısmında yaklaşı $1,00 \mathrm{~m}$ genişliğe sahip bir giriş veya kapı açıklığ Botay'daki 14 nolu konutun kuzeydoğu kısmında giriş veya kapı açıklığının önünde dört direğin dikilmiş olabileceğini gösteren çukur izlerine rastlanılmıştır. Buradan hareketle girişlerin dışa doğru taşkın bir şekilde inşa edildiği görülmüştür. Ayrıca konutun tabanı zeminden yaklaşık

${ }^{22}$ A. Kislenko, Opıt Rekonstruktsii Eneoliticheskogo Jilişa, Problemı rekonstruktsii hozaistva i tehnologiy po dannım arheologii. V. Zaibert editörlüğünde, İA NAN Respubliki Kazahstan, Petropavlovsk, 1993,s.122-127

${ }^{23}$ agm, s. 129. 
0,70-0,75 m aşağıda olması nedeniyle giriş veya kapı seviyesine ulaşılması için basamaklı bir merdiven inşa edilmiş olmalıdır. Bu durum giriş açıklıklarının yapının beden duvarından yaklaşık $1,00 \mathrm{~m}$ dışa taşkın yapılmasına temel teşkil etmektedir. Diğer taraftan Botay konutlarında giriş yönünün tespiti için bazı etnografik bilgilerden de yararlanılmıştır. ${ }^{24}$ Türk halklarının geleneksel çadırlarının mekân kullanım özelliklerinden hareketle bazı ipuçlarına ulaşılmıştır. Türk çadırının girişi doğu yünündedir; eşik önü bölümü işlevsel bir bölgedir ve giriş çıkış aktivitelerine uygun şekilde düzenlenmiştir. Çadırın sol tarafı erkek bölümü, sağ tarafı ise mutfak gereçlerinin bulunduğu kadın bölümüdür. Kapının tam karşısında ve tam merkezde konumlandırılan ocağın arkasında bulunan bölüm konukların kabul edildiği ve en kıymetli eşyaların sergilendiği özel bir köşedir. Bu bölüme günümüzde Kazakça ve bazı diğer Türk lehçelerinde "tör" denilmektedir. ${ }^{25}$ Kazı buluntularının çoğunlukla konutların kuzeydoğu kısmından ele geçmesi ve güneybatı kısımda ise çok az buluntunun tespit edilmesi, güneybatı kısmın uyku ve dinlenme için ayrılmış olduğunu gösterdiği ifade edilmektedir ${ }^{26}$.

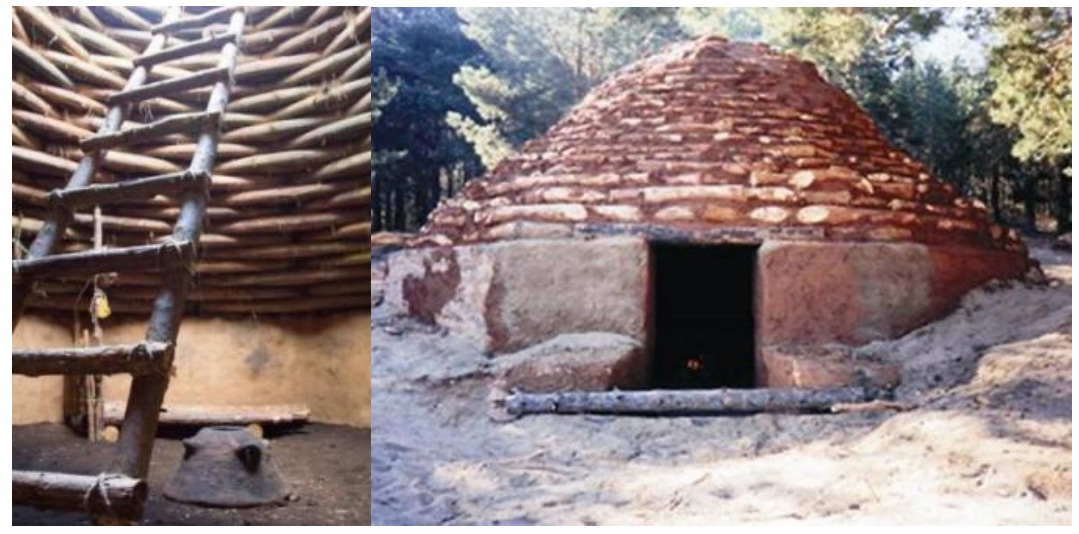

Fotoğraf 2 ve 3: Botay’da deneysel testlerle şekillenen konut rekonstrüksiyonu

Türk çadırlarında görülen mekân kullanım özelliklerin benzerlerini Botay konutlarında bulmak mümkündür. Örneğin, Botay konutlarının merkezinde de yuvarlak biçimli bir ocak bulunur, döşek veya ahşap sekiler genellikle yapıda girişin tam karşısında yani ocağın arkasında bulunur. Duvarlarda çok sayıda dolap nişleri yer almaktadır. ${ }^{27}$ Prof. Dr. Viktor Zaibert'e göre Botay konutlarında saptanan neredeyse bütün bulguların geleneksel Türk çadırlarının iç mekân düzenlemesiyle benzer veya uyumlu olduğu görülmektedir. Botay kültürü üzerine araştırma yapan arkeologlar "kırlangıç" veya tütekli örtüye sahip dairesel planlı konutların Türk çadırlarının prototipi olduğu konusunda hemfikirdir. ${ }^{28} \mathrm{Bu}$ görüşe katılmakla birlikte bir noktanın özellikle belirtilmesi gerektiğini düşünmekteyim. Ülkemizde yaygın düşünce Türk mimarisinin özellikle geleneksel konut mimarisinin oluşum ve gelişiminde Orta Asya Türk çadırının büyük ölçüde etkili ve belirleyici olduğudur. Çadırdan konut mimarisine geçildiği ve mimarinin çadırlar model alınarak şekillendiği düşünülmektedir. Arkeolojik veriler ise Türk çadırının oluşumunda Kalkolitik döneme tarihlenen Botay konutlarının büyük etkilerinin olduğunu ortaya koymaktadır.

${ }^{24}$ agm, s. 127

${ }^{25}$ E. Lvova İ. Oktyabrskaya, A. Saglasov, M. Usmanova, Traditsionnoye mirovozreniye Tyurkov Yujnoy Sibiri.

Veşniy mir , Novosibirsk, 1988, s. 66-67.

${ }^{26}$ Kislenko, 1993, agm. s.129.

${ }^{27}$ Zaibert, 1993,age. s.34

${ }^{28}$ Viktor Zaibert, "Botaiskaya kultura- Matrisa Stepnoy Tsivilizatsii”, Margulan Okuları 2019, Nur-Sultan, 2019, s. 109., Kislenko, 1993, agm, s. 136. 
Botay konutlarında ahşap örtülerin herhangi bir direk veya sütun gibi taşıyıcı unsurlara gerek duyulmadan inşa edilmesi İç Asya'nın mimarlık tarihi için büyük bir gelişme hatta Prof. Dr. Viktor Zaibert'in tabiriyle "Eureka"dır. ${ }^{29}$ Orta Asya kültür coğrafyasında atın ilk evcilleştirildiği kültür olmasının yanı sıra bilinen en erken tarihli ahşap tütekli örtü örneklerini göstermesi ve Proto-Türk veya Türk topluluklarınca kullanılan çadırların prototipinin Botay konutlarından ortaya çıktığının tespitinin bilimsel değeri çok büyüktür. Son yıllarda yapılan genetik çalışmalar sonucunda Botay kültürü mensuplarının Proto Hint-Avrupalı dil konuşan topluluklarla hiçbir bağlantısı olmadığı aksine Doğu Asyalı Ata (East Asian Ancestry) soyundan geldikleri ve günümüzde Orta Asya ve Sibirya ${ }^{30}$ coğrafyasında yaşamakta olan Türk dilli halklarla ilişkili olduğu tespit edilmiştir.

\section{2. Tunç Çağı’nda Tütekli Örtü}

Başlangıcı Kalkolitik döneme inen ve M.Ö. 16. yüzyıla yani Orta Tunç Çağına kadar varlık gösteren Botay kültürü konutlarında görülen ahşap tütekli örtünün zamanla mimari bir geleneğe dönüştüğü ve Orta Asya coğrafyasında Botay’ı izleyen tarih dönemlerinde mimaride yaygın uygulandığı saptanmıştır. Çalışmamızda sırasıyla Tunç Çağı, Demir Çağı, İlk ve Orta Çağlarda Orta Asya geleneksel mimarisindeki ahşap tütekli örtü örnekleri ele alınarak kültürel süreklilik olgusu net şekilde ortaya konulmuştur. Kalkolitik dönemde bilinen ilk örnekleri Botay'da tespit edilen ahşap tütekli örtünün Tunç Çağından itibaren çevre yöre ve bölgelere doğru yayıldığ anlaşılmaktadır. $\mathrm{Bu}$ nedenle öncelikle Tunç Çağında Orta Asya'da görülen Andronovo kültürüyle ilişkili mimaride görülen tütekli örtü uygulamaları üzerinde durulması gerekir.

Orta Asya coğrafyasında Tunç Çağı yerleşimlerine yönelik çalışmaları yürüten A. Margulan $^{31}$, M. Gryaznov ${ }^{32}$, K. Salnikov ${ }^{33}$ ve E. Kuzmina ${ }^{34}$ gibi arkeologların uzun y1llar boyunca yürüttükleri kazı araştırmaları sonucunda kare kesitli bir açıklıkla sonlanan "basamaklı piramidal" veya tütekli ahşap örtü sisteminin çok sayıda örneğinin bulunduğu tespit edilmiştir. Özellikle Sibirya ve Kazakistan'da görülen "Andronovo kültürel birliği” 35 olarak tanımlanan toplulukların konut ve mezar mimarisinde yaygın olarak tütekli ahşap örtü kullandığı anlaşılmıştır.

Kazak Arkeolojisinin kurucusu Alkey Hakanulı Margulan'a göre Orta ve Kuzey Kazakistan'da Tunç Çağının en yaygın konut tipi kare veya dikdörtgen planlı ve merkezde ahşap tütekli örtüye sahip yapılardır (Çiz. 3). Kazılarda ahşap tütekli örtünün konut mimarisinin yanı sıra kurgan mimarisinde de kullanıldığına dair arkeolojik bulgulara ulaşılmıştır. En iyi örneklerin başında, Begazı, Aksu-Ayul 2 (Çiz.4 ve 5), Sangıru, Bugulu, Dandıbay 11 ve Atasu gibi Tunç Çağı yerleşim merkezleri ve kurganları gelmektedir ${ }^{36}$.

\footnotetext{
${ }^{29}$ Viktor Zaibert, agm. 2019, s. 109.

${ }^{30}$ Peter de Barros Damgaard vd., The first horse herders and the impact of early Bronze Age steppe expansions into Asia, Science, 360, say1 1422, 2018, s. 1-4.

${ }^{31}$ A. Margulan, K. Akişev, M. Kadırbayev, A. Orazbayev, Drevnyaya kultura Tsentralnogo Kazahstana, Alma-Ata, 1966, s. 207.

${ }^{32}$ M. Gryaznov, "Zemlyanki Bronzovogo Veka bliz hutora Lyapicheva na Donu”, KSIIIMK, Say1 50, 1953, s. 145.

${ }^{33}$ K.V. Salnikov, , "Bronzovyi Vek Yujnogo Zauralya”, MİA,Moskva, 1951, Cilt 2, s. 106-109.

${ }^{34}$ E. Kuzmina, Dve linii razvitiya domostroitelnih traditsiy v Starom Svete, Problemi Arheologii Uralo-Kazahstanskih stepey, Çelyabinsk, 1988, s.31-46.

${ }^{35}$ Günümüzde yayılma sahasının geniş olması ve bazı belirgin bölgesel farklılıklardan dolayı tek tipli Andronovo kültürü yerine Andronovo tarihi-kültürel topluluklar birliği tabiri kullanılmaktadır.

${ }^{36}$ A. Margulan, T. Basenov, M. Mendıkulov, Kazakstan Arhitekturası, Almatı, Öner baspas1, 2010, Cilt 1, s.35-37, 84-90.
} 

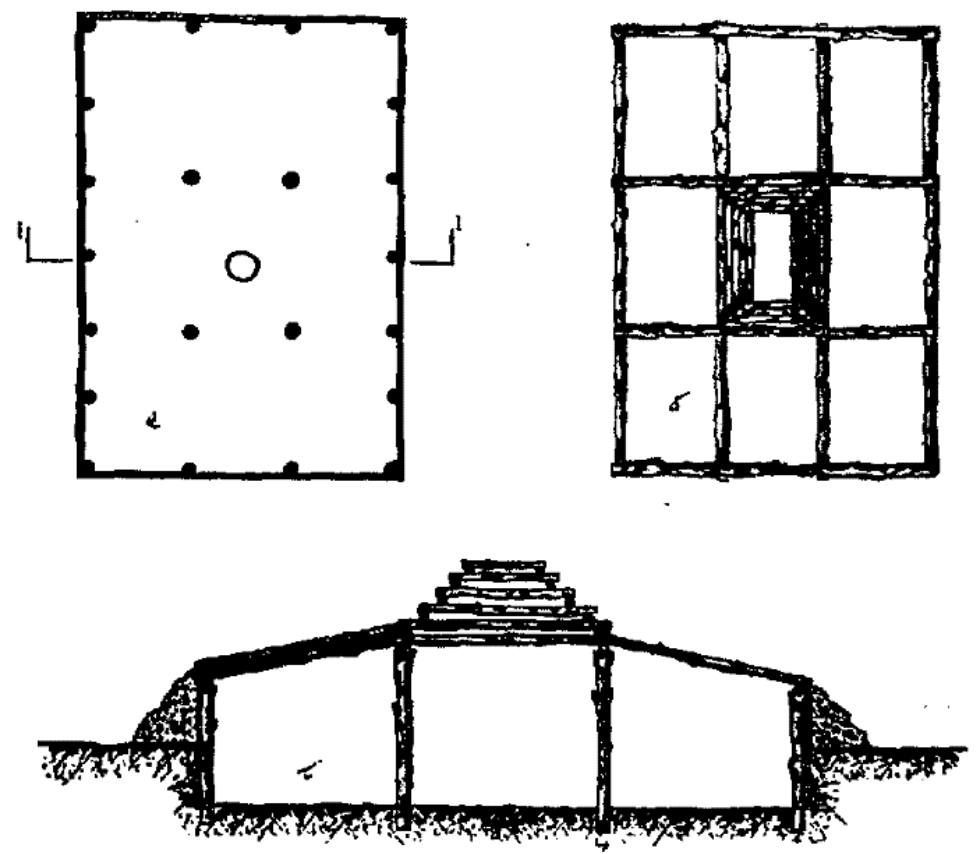

Çizim 3: Kazakistan'da Tunç Çağına ait bir konutunun restitüsyon kesit planı. A. Margulan

Kazakistan'daki önemli Tunç Çağı kültürlerinden ve yerleşimlerinden biri Atasu'dur. Atasu döneminde Botay'da olduğu gibi konutlar zemin seviyesinin altına kazılarak oluşturulan dikdörtgen veya kare planlı bir çukur üzerine inşa edilmektedir. Konutun çukur kısmı yapının beden duvarının yaklaşık yarısına kadar bir düzeye ulaşmaktadır. Söz konusu dönemde Botay'dan farklı olarak duvarlarda malzeme olarak taş kullanımı dikkat çekmektedir ancak duvarın ortasında dolgu malzemesi olarak toprak ve çakıl taş karışımı uygulanmaktadır. Örtü ise iki sıra halinde ahşap direkler tarafından taşınmaktadır ve bu nedenle üç sahınlı hale gelen konutların yan sahınlarında düz ve hafif eğimli ahşap tavan örtü tercih edilirken orta sahınların merkezinde genelde hem aydınlatmayı hem de ocaktan çıkan dumanın tahliyesini sağlayan tütekli ahşap örtü uygulaması (Çiz. 3) gözlenmektedir. ${ }^{37}$

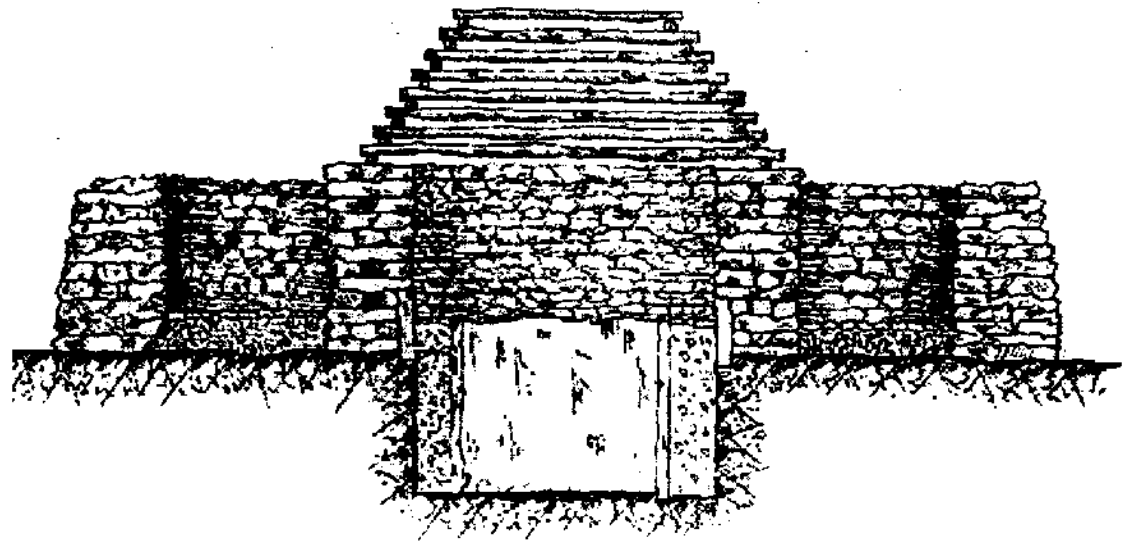

Çizim 4: Aksu Ayulu II. kurganın restitüsyon kesiti, A. Margulan, 2010, s. 83

\footnotetext{
${ }^{37}$ A. Margulan, T. Basenov, M. Mendikulov, Arhitektura Kazahstana, Alma-Ata, 1959, s. 24-26, 35.
} 


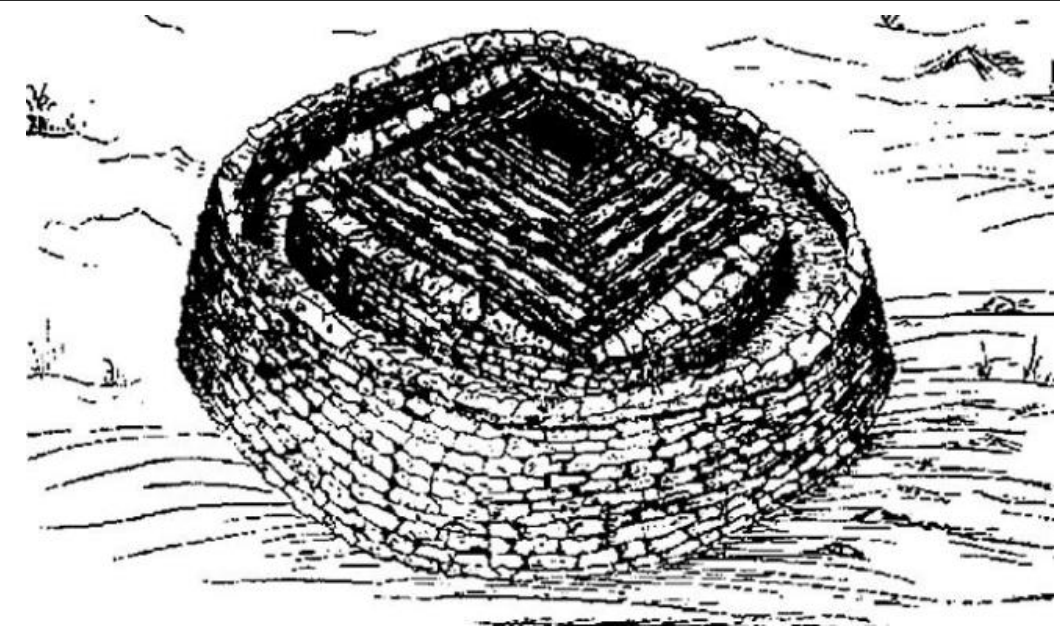

Çizim 5: Aksu-ayulu II. kurganı örtü restitüsyonu, A. Margulan, 2010, s. 83.

Ayrıca Kazakistan'da Tunç Çağı'nda kare ve dikdörtgen planlı yapıların yanı sıra dairesel planlı yapıların da inşa edildiğine dair arkeolojik veriler mevcuttur. Kazılarda Tunç Çağı'na tarihlenen ahşap tütekli örtüye sahip dairesel planlı ve birbirine koridorla bağlı konutların kalıntılarına rastlanmıştır (Çiz. 6). Bu tür yapıların hem çukur barınak tipinde hem de zemin seviyesi üzerinde inşa edilen çeşitleri bulunmaktadır. Örneğin, Kuzey Kazakistan'da Kökşetau vilayetinin Tiyınşı ilçesindeki Şagalalı Çayı kıyısında konumlanan ve Şagalalı olarak adlandırılan Tunç Çağı yerleşimindeki 9 nolu konut, çukur barınak iken 13 ve 14 nolu konutlar ise yer üstü inşa edilmiştir. Ancak her iki tip konutların ortak yönü ahşap tütekli örtüye sahip olmalarıdır. Şagalalı'da kazıları yürüten A. Orazbayev, arkeolojik katmanlarda çok miktarda ahşap kalıntılara rastlandığını hatta bazı konutların tamamen ahşap tomruklardan inşa edildiği sonucuna ulaşıldığını belirtmektedir. ${ }^{38}$ Bununla birlikte Kuzey Kazakistan'da Kostanay vilayetinde, Tobıl nehrinin kıyısında konumlandırılan ve Alexeevka olarak adlandırılan Geç Tunç Çağı yerleşiminde kazıları yürüten O. Krivtsova-Grakova da Şagalalı konutlarıyla çok benzer özelliklere sahip dairesel planlı ve ahşap tütekli örtüye sahip konutlara ait arkeolojik buluntu ve kalıntılara ulaşıldığını ifade etmiştir ${ }^{39}$.

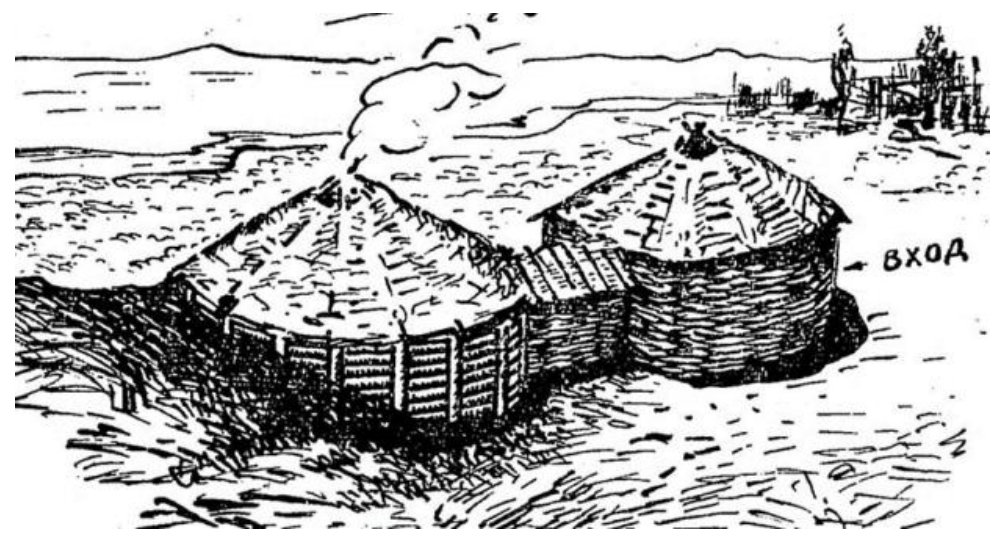

Çizim 6: A. Orazbayev'in Şagalalı yerleşiminde saptanan konutların restitüsyonu.

\footnotetext{
${ }^{38}$ A. Orazbayev, Poseleniye Çaglinka (Şagalalı), Nekotorye formy i tipı jiliş, Po sledam drevnih kultur Kazahstana, Nauka, Alma-Ata, 1970, s. 129-144.

39 O. Krivtsova-Grakova, Alexeevskkoye poseleniye i mogilnik. Trudı Gosudarstvennogo istoriçeskogo muzeya, Moskva, Sayı 17, 1948, s. 57-164.
} 
Orta Asya'da Tütekli (Kırlangıç) Örtünün Kökeni ve Tarihî Gelişim Aşamaları Üzerine bir Değerlendirme

\section{IV.3. Demir Çağı'nda (İskit-Saka Dönemi) Tütekli Örtü.}

Geç Tunç Çağı ve Demir Çağı'na tarihlendirilen Güney Kazakistan'da Kızılorda Vilayeti’nde bulunan Tagisken'de arkeolojik kazı verilerine göre ahşap tütekli örtü örnekleri tespit edilmiştir. Seyhun (Sirderya) nehrinin bir kolu olan İnkar Derya'nın kıyısındaki Tagisken tepesinde oldukça anıtsal bir mezar kompleksi konumlandırılmıştır (Çiz. 7). 1960'lı yıllarda yürütülen arkeolojik kazı çalışmaları sonucunda Tagisken'deki mezar anıtlarından dördü Geç Tunç Çağı'na ve biri ise Demir Çağı'na (İskit-Saka dönemine M.Ö. 6.-5. yüzyıllara) tarihlendirilmiştir. Geç Tunç Çağına tarihlenen 6 nolu anıt mezar dıştan dairesel içten kare planlıdır. Yapının çapı $15 \mathrm{~m}$, kerpiçten inşa edilen duvarlarının kalınlığı ise $4 \mathrm{~m}$ olarak ölçülmüştür. İç mekân genişliği yaklaşık olarak 50 $\mathrm{m}^{2}$ olan mezarın tabanı zemin seviyesinin 1,50 m altındadır. Ayrıca anıt mezarın dıştan dairesel planlı bir duvarla etrafı çevrilmiş ve duvar ile yapı arasında yaklaşı $2,00 \mathrm{~m}$ mesafe bırakılmıştır. ${ }^{40} \mathrm{M}$. Gryaznov'a göre 6 nolu mezar anıtı 6,00-8,00 m arasında yüksekliğe sahip iken etrafı yaklaşık 3,00 m kalınlık ve yükseklikte bir kerpiç duvarla çevrilmiştir. Anıt mezarın içinde yaklaşık 100 adet tunç çivi ve 60'a yakın keramik parçaları bulunmuştur. M. Gryaznov'a göre tunç çivi buluntuları, iç mekân yüzeylerine halı asılmış olabileceğine işaret etmektedir. Yapının örtüsü ise tamamen korunamamıştır ancak kazı çalışmalarında elde edilen buluntular ahşap tütekli örtü uygulamasının varlığını ortaya koymaktadır. ${ }^{41} \mathrm{M}$. Gryaznov'un bu tespitinin doğruluğuna birçok araştırmacı ve arkeologlar da katılmaktadır. ${ }^{42}$

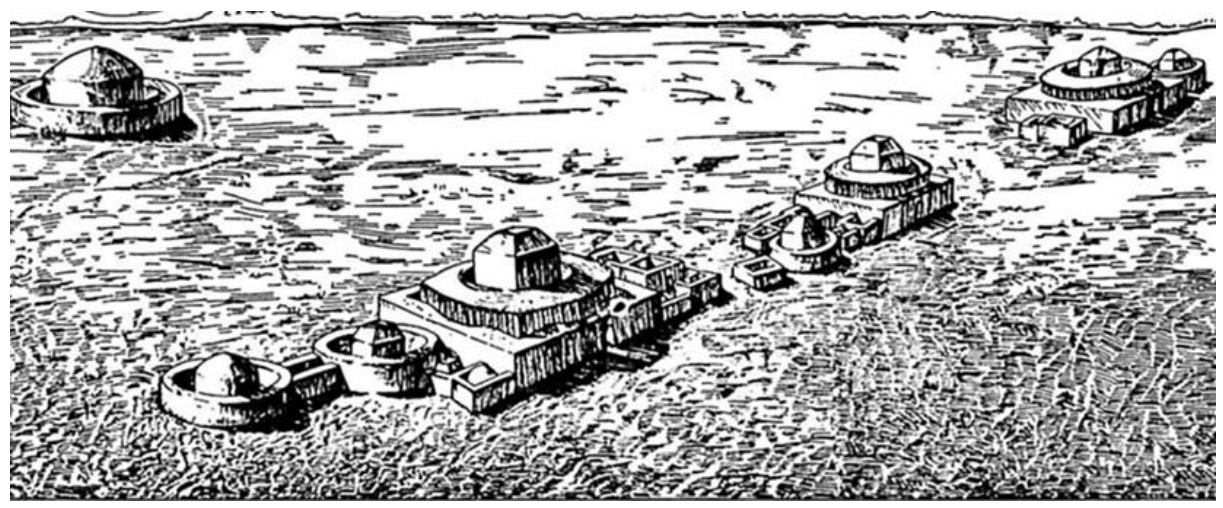

Çizim 7: Tagisken'deki mezar anıtlarının genel restitüsyonu (M. Gryaznov)

Demir Çağı'nda İç Asya'da görülen kültürlerin mimarisinde ahşap tütekli örtü uygulamasının bir gelenek haline geldiği ve daha da yaygınlaştığ çeşitli kazılardan gelen verilerden anlaşılmaktadır. Orta Kazakistan'da yapılan kazılarda ortaya çıkarılan konutların duvarlarında kullanılan inşa malzemesinde yöreden yöreye ve dönemden döneme yer yer bazı farklılıklar görülmesine rağmen ahşap tütekli örtülerin vazgeçilmez tek tercih olması dikkat çekmektedir. ${ }^{43}$

Öncelikle Demir Çağı'nda madencilikte ve maden işlemede önemli değişim veya gelişmelerin yaşanması nedeniyle Orta Asya'da sosyal-ekonomik ve teknolojik köklü değişiklikler meydana gelmiştir. Demirin işlenmesi ve araç gereçlerin demirden üretilmeye başlanmasıyla bakır ve tunca dayalı üretim terkedilme sürecine girmiştir. Bunun yanı sıra meydana gelen büyük iklim değişiklikleri de Tunç Çağı yerleşik topluluklarının Demir Çağı'nda mevsimsel göçebeliğe geçmelerini zorunlu hale getirmiş̧ir. Bu durum, Orta Asya geleneksel konut mimari geleneğinin

${ }^{40}$ M. Gryaznov, Vostochnoye Priaralye, Srednyaya Aziya v epohu kamnya i bronzı, Moskva-Leningrad, 1966, s. 233236.

${ }^{41}$ age, s 233-236.

42 B. Glaudinov, Istoriya Arhitekturl Kazahstana, KazGASA, Almat1, 1999, s. 28.

${ }^{43}$ Margulan vd., 1959, age, s. 48 
göçebe yaşam koşullarına uyumlu hale gelmesiyle sonuçlanmıştır ancak geleneksel konut mimarisi tamamen ortadan kalkmamıştır. Böylece taşınabilir ve hızlıca kurulup sökülebilen konut ihtiyacını karşılamaya yönelik Türk çadırına geçiş süreci yaşanmıştır. İç Asya'da Türk çadırlarının ilk olarak M.Ö. 9.-8. yüzyıllarda Karasuk kültürü döneminde ortaya çıktığı ve bu değişimin mevsimsel göçebe hayvancılığa geçişle ilgili olduğu sanılmaktadır. Henüz Botay konutlarının bilinmediği 1950'li yıllarda dairesel planlı ve ahşap tütekli örtülü evlerin yurt olarak adlandırılan çadırların kaynağı olduğu düşüncesi ifade edilmiştir. ${ }^{44}$ Bu görüşe Kazak arkeologlar A. K. Margulan ve A. Orazbayev de katılmaktadır.

Bununla birlikte Demir Çağı'nda Kazakistan'ın güney bölgelerinde tarım, mevsimsel göçebe hayvancılı̆̆ın gerisine düşmesine rağmen hala en önemli ekonomik faaliyetlerden biri olmayı sürdürmüştür. Bu durum, Orta Asya'nın birçok bölgesine nazaran yerleşik hayat olgusunun tamamen ortadan kalkmadığını göstermektedir. Örneğin, Sirderya kıyısındaki Jartöbe ve Karatöbe, Çu ve Talas nehri kıyısında Jumabaytöbe ve Kulan, Arıs kıyısında Juantöbe, Koskuduk ve Maybalık gibi birçok Demir Çağı yerleşimlerinde İskit-Saka döneminden itibaren inşa edilen birçok baraj ve sulama kanalları sayesinde sulu tarım yapıldığı arkeolojik bulgularla kanıtlanmıştır. ${ }^{45}$

Demir Çağı'nın başlarında M.Ö. 9.-8. yüzyıllarda (Erken İskit Dönemi) Kazakistan coğrafyasında inşa edilen konutların Kalkolitik ve Tunç Çağı konutlarından en önemli farklarından biri zemin seviyesinin üstünde yapılmalarıdır. Ayrıca bu dönemde konutlar coğrafi şartlara göre taş, kerpiç ve ahşap gibi farklı malzemelerden inşa edilmeye başlamıştır. Kare, çokgen veya dairesel planlı olmaları yönüyle fark gözlenmemektedir. Yine dönem konutlarının en belirgin özelliklerinden biri ahşap malzemeden inşa edilen piramidal tütekli örtüdür. Ahşap yönünden çok zengin olan Kuzey Kazakistan'da duvarları tomruk veya kalaslardan yığma tekniğiyle birbirine geçmeli inşa edilen çokgen (genellikle altıgen ve sekizgen) planlı konutlar görülmeye devam etmiştir. Bu tip konutların örtüleri de mimari plan özelliklerine uyumlu piramidal ahşap tütekli örtü uygulamaları şeklindedir. A.K. Margulan'a göre bu dönemin kare veya dairesel planlı konutlarında ahşap tütekli örtüleri, yapının merkezindeki ocağın dört köşesine dikilen direkler taşımaktadır. ${ }^{46}$ Ayrıca Orta Kazakistan'daki İskit-Saka dönemi yerleşimlerine ait konutlarda da ahşap tütekli örtü bulunmaktadır. Örneğin A. Beisenov, Orta Kazakistan'daki Tüyetas yerleşiminde dairesel planlı bir konutun ahşap tütekli örtüye sahip olduğunu ifade etmektedir. ${ }^{47}$

Altaylar'da İskit-Sakalar üzerine yaptığı arkeolojik çalışmalarla tanınan Sergey Rudenko, İskitlerin 3 tip konutları olduğunu belirtmektedir: Birinci tip, huş ağacı gövdesinden inşa edilen tabanı dairesel planlı ve örtüsü koni biçiminde son bulan alaçık olarak adlandırılan çadırlardır. İkinci tip, araba üstüne konumlandırılan keçeden çadırlar (yurtlar) ve üçüncü tip ise oldukça sağlam tomruk ve kalaslardan inşa edilen ahşap evlerdir. ${ }^{48}$

Döneminin mimari özellikleri konutların yanı sıra kurganların inşasına da yansımaktadır. Özellikle kurganlardaki ahşap defin odaları ait oldukları dönemin konut mimarisinden izler taşımaktadır. Ahşap mezar odaları, tomruk ve kalaslardan inşa edilen evlerin adeta birer modelidir. Bu görüş Orta Asya arkeolojisinde genel kabul görmektedir. Ancak mezar odaları ile dönemin ahşap konutları arasındaki en temel fark ısıtma ve aydınlatma ihtiyacına yönelik ocak

${ }_{44}^{44}$ S. Kisilev, Drevnaya İstoriya Yujnoy Sibiri, Moskva, 1951, s. 252-254.

${ }^{45}$ Margulan vd, 1959,s.43; Margulan,2010, age, s.,125

${ }^{46}$ Margulan, 2010, age, s. 17-18.

${ }^{47}$ Arman Beysenov, Krugloye jilişe sakskoy epohi, Samarski nauçnıy vestnik, Cilt 6, № 1 (18), 2017, s. 96.

${ }^{48}$ S. Rudenko, Kultura naseleniya Gornogo Altaya v skifskoye vremya, İzdatelstvo AN SSSR, Moskva, Leningrad, 1953, s. 79 
ve tütekli örtülerin uygulanmamasıdır. Kurganlarda söz konusu ihtiyaçların olmamasının yanı sıra kurgan örtüsünde tonlarca ağırlığa sahip taşların yığılması nedeniyle mezar odaları düz tavanlı inşa edilmiş ve üzerine çok sayıda kalaslar uzatılarak söz konusu ağırlığın taşınması amaçlanmıştır. Ayrıca Altaylar ve Kazakistan'daki İskit kurganlarında tomruktan inşa edilmiş mezar odaları hem zemin seviyesinin altındaki çukurlarda (Pazırık, Berel, Tuyakta, Başadar, Esik) hem de zemin seviyesinde veya üzerinde (Arjan1, Eleke Sazı 4, Şilikti Baygetöbe, Taldı 2) konumlandırılmıştır.

\section{4. Hun Döneminde Tütekli Örtü}

Bununla birlikte Hun döneminde konut mimarisi hakkında önemli görseller ve bilgiler sunan Boyar Dağ (Hakas Türkçesinde: Poyar Tağ) kaya resimlerinin önemi yadsınamaz. Günümüzde Rusya Federasyonu'na bağlı Hakasya Cumhuriyeti'nde bulunan Troitsk köyünden $6 \mathrm{~km}$ mesafededir. Boyar Dağ'daki kaya resimleri içinde özellikle Hun dönemine ait bir köyünün betimlemelerine yer verilmiştir. Boyar Dağ'da iki önemli kaya resmi grubu olduğu bilinmektedir: Büyük Boyar Dağ ve Küçük Boyar Dağ kaya resimleri.

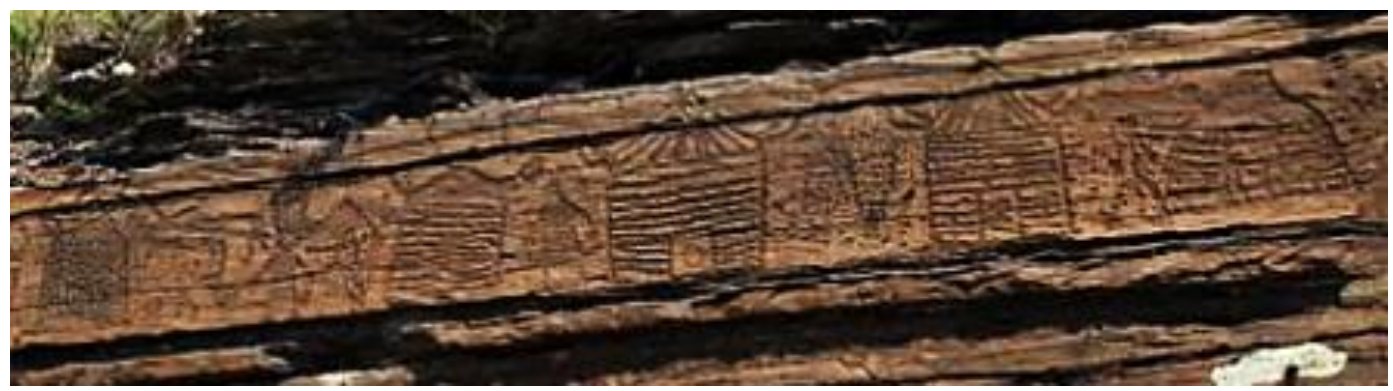

Fotoğraf 4: Küçük Boyar Dağ Kaya Resimlerinde betimlenen evler ${ }^{49}$

Küçük Boyar Dağ kaya resimleri ilk defa 1904 yılında A. Adrianov tarafindan keşfedilmiştir. Kaya resimleri kayıt altına alınmak üzere fotoğraflanmış ve gravürlerin estampajları alınmıştır. $\mathrm{Bu}$ estampajlar daha sonra M. Gryaznov tarafından incelenerek yorumlanmış ve yayınlanmıştır. Yaklaşık olarak 50 parçadan oluşan kaya resimlerindeki betimlemeler bir tür keskin veya sivri uçlu aletle kaya yüzeylerine çizilmiştir. Genel olarak tüm betimlemelerin arasında uyumlu bir düzen gözlenmekte ve çizim tekniği ile üslup yönünden de farklılıklara rastlanmamaktadır. Kısacası kaya resimlerinde dönem veya üslup farkına işaret eden herhangi bir unsur tespit edilmemiştir. $^{50}$

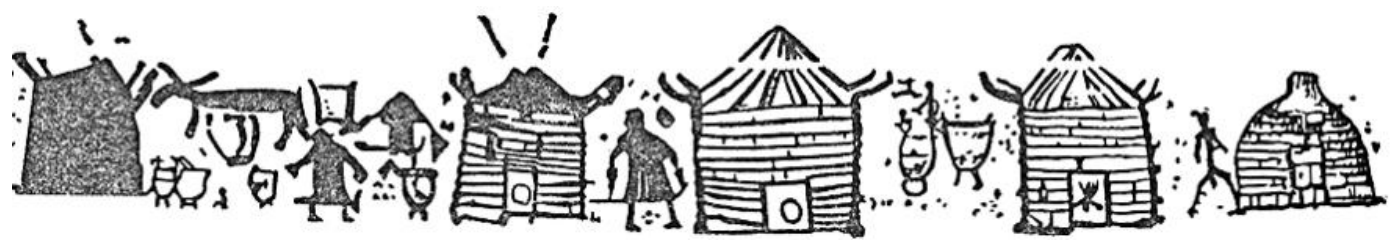

Çizim 8: Küçük Boyar Dağ Kaya Resimlerinde betimlenen evler (M. Gryaznov)

Küçük Boyar kaya resimlerinde toplam 5 adet yapı betimlenmiştir (Foto. 4, Çiz. 8). M. Gryaznov'a göre betimlenen yapıların üçü kare veya dikdörtgen planlı iken çatıları dört köşeli piramidal örtüye sahiptir. Yapıların beden duvarları üzerindeki yatay çizgiler, duvarların ahşap tomrukların birbiri üzerine bindirilmesi ve birbirine geçirilmesiyle inşa edildiği göstermektedir. Çatının üzerine çizilen yan çizgiler ise örtü üzerine yalıtım maksatlı konulan ağaç kabuklarını

49 http://russights.ru/post_1425239264.html

${ }^{50}$ M. Gryaznov, "Boyarskaya pisanitsa", Problemı istorii materialnoy kulturı, No. 7-8, 1933, s.41 
sabitleyen kalas veya ağaç dallarını göstermektedir. Örtünün alt kısmından yana uzanan çizgiler ise çatı kirişlerini bir arada tutan yatay kirişlerin uçlarını veya kalasları taşıyan kazıkların uçlarını betimlemektedir. ${ }^{51}$

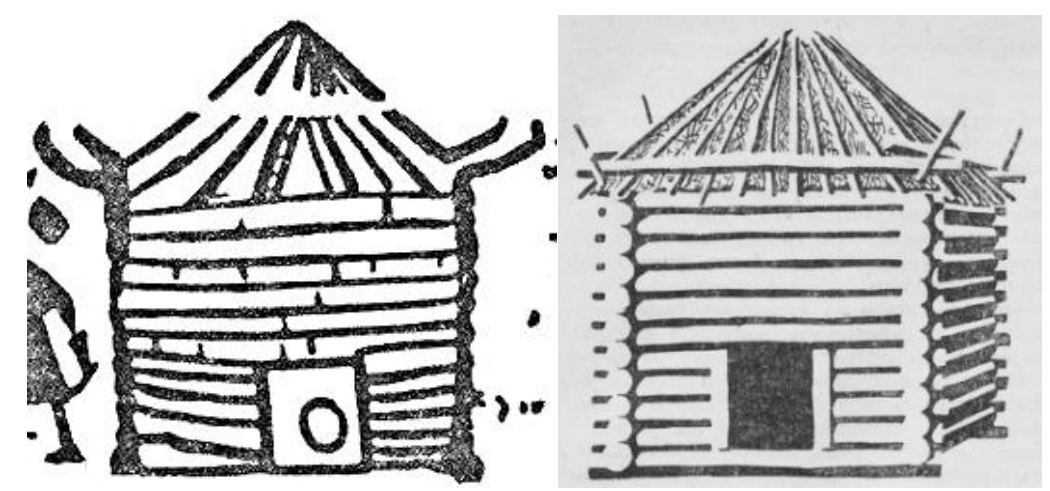

Çizim 9 ve 10: Küçük Boyar Dağ'da bir evin tasviri ve restitüsyonu. (M. Gryaznov)

A. Adrianov, dışa doğru taşıntı yapan çizgilerin geleneksel Çin mimarisine özgü örtüyü betimlediğini düşünmüştür (Çiz. 9). Ancak bu fikre katılmayan M. Gryaznov bunun büyük bir yanılg1 olduğunu ve benzer örnekleri bulmak için o kadar uzağa gitmeye gerek olmadığını ve Sibirya'da günümüzde Altay Cumhuriyetinde yaşamakta olan Tuba Türklerine ait herhangi bir eve bakmanın yeterli olduğunu savunmuştur. Ayrıca, Tuba Türklerinin geleneksel tomruk veya kütük evlerinin örtüsünde kare kesitli bir açıklık bulunduğuna değinen $\mathrm{M}$. Gryaznov kaya resimlerinde betimlenen konutların giriş açılıklarında yer alan çembere benzer çizginin evin ortasında konumlandırılan ocağ (Çiz. 9) temsil ettiğini belirtmiştir ${ }^{52}$. Ayrıca kaya resminde yer alan sağdan ikinci konutta ocakta yanan alevin betimlenmesi bu görüşü doğrulamaktadır (Çiz. $8)$.

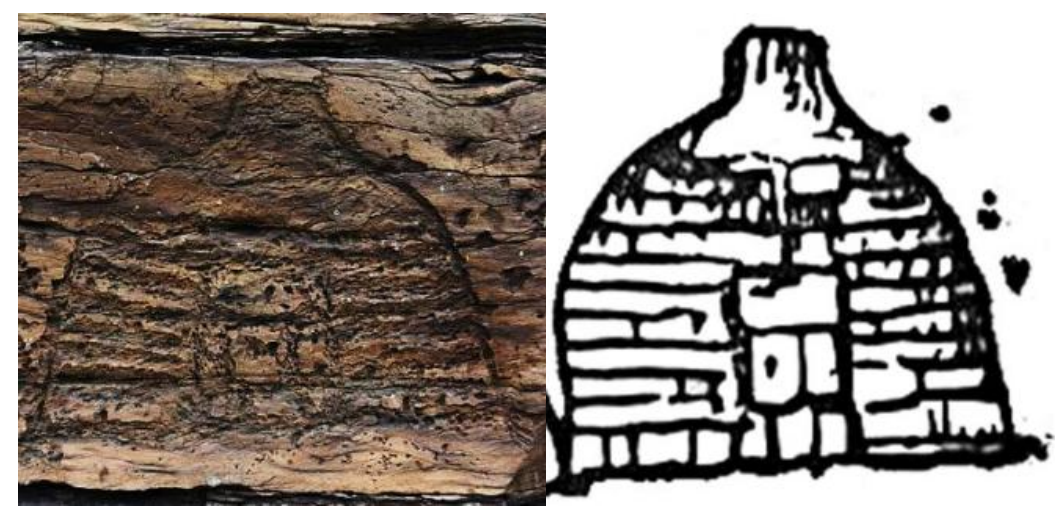

Fotoğraf 5: Küçük Boyar Dağ'daki bir ev tasviri ${ }^{53}$ Çizim 11: ev tasvirinin çizimi

Küçük Boyar Dağ kaya resimlerindeki konut betimlerinden en sağda yer alanı ise dairesel veya çokgen planlı bir yapıyı resmetmektedir (Foto. 5; Çiz. 11). M. Gryaznov bu tasvirin kesinlikle bir keçe yurt veya çadır olmadığını, beden duvarlarındaki yatay çizgilerle detay verilmesinin amaçsız veya rastgele bir husus olmayıp konutun mimari özelliğini yansıttığını belirtmektedir. ${ }^{54}$ Beden duvarlarının detayında verilen yatay çizgilerin yapının inşasında

51 agm, s. 41-42.

52 agm, s. 41-45.

${ }^{53}$ http://russights.ru/post_1425239264.html

54 Gryaznov, 1933, agm, s. 41-45. 
kullanılan tomrukları betimlediği anlaşılmaktadır. Bu nokta $\mathrm{M}$. Gryaznov'un görüşüne katılmaktayım. Söz konusu tasvirde beden duvarları ahşap tomruklardan inşa edilen dairesel planlı ve örtüsü yukarı doğru daralan "bacalı" veya uzun tütekli bir yapı betimlenmektedir (Foto. 4). Benzer özellikler Saha (Yakut) Türklerine ait geleneksel konutlarda açıç̧a görülmektedir (Çiz. 12, 13). Burada yapının örtüsü üzerindeki baca bir tütek uzantısı şeklindedir ve bu durum piramidal tütekli örtü tekniğiyle ilişkili olmalıdır. Ayrıca, Küçük Boyar Dağ kaya resimlerinde betimlenen konutların en solda olanı (Çizim 8) ise diğerlerinden farklı şekilde mimari detayları verilmeksizin resmedilmiştir.

Ahşap malzeme yönünden zengin bir yöre olan Sibirya' daki geleneksel konut mimarisinde de ahşap tütekli örtü uygulamaları geçmişten günümüze kadar uygulanageldiği görülmektedir. Örneğin, Sibirya'da Saha (Yakut) Türklerinin geleneksel konut mimarisinde ahşap malzemeden inşa edilmiş çokgen kesitli ve yukarı doğru daralarak piramidal bir görünüm kazanan tütekli örtüye sahip yapıları görmek mümkündür. Küçük Boyar Dağ kaya resimlerinde betimlenen Hun köyüne ait konutların benzerlerini ressam M. Nosov’un 17. yüzyıla ait bir Yakut köyünü tema edinen resim (Res. 2) ve çizimlerinde de görmekteyiz (Çiz. 12, 13).

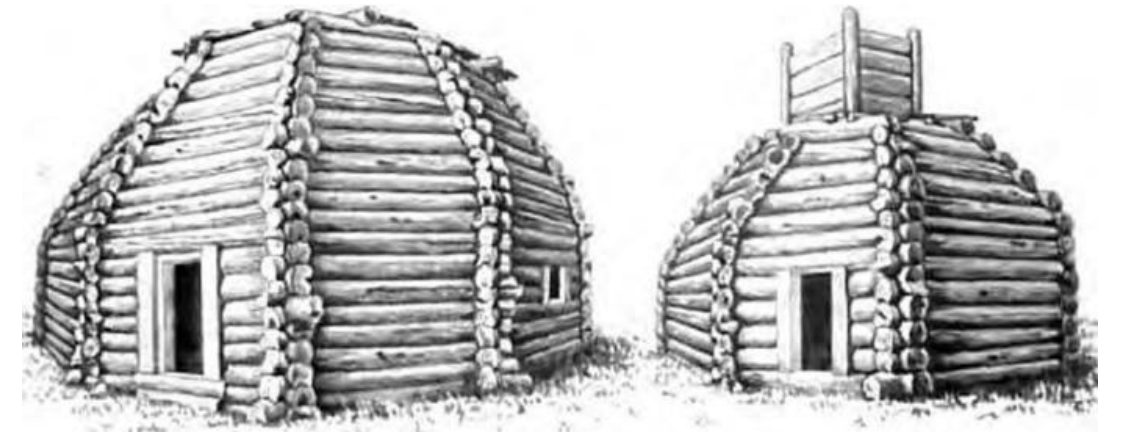

Çizim 12 ve 13: Ressam M. Nosov’un albümünde yer alan Saha Türklerine ait çokgen planlı geleneksel konutların çizimleri ${ }^{55}$

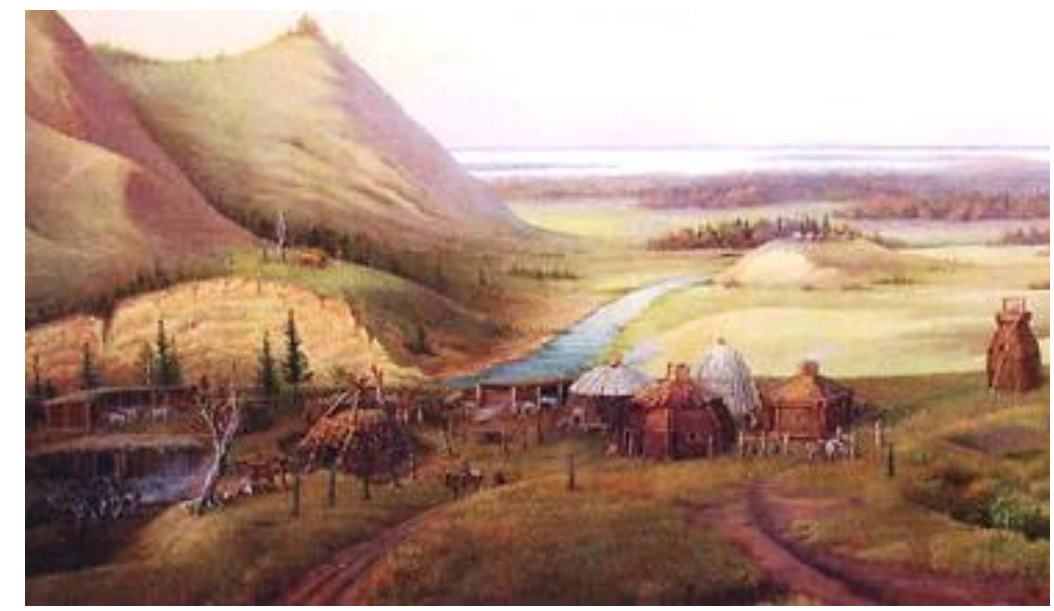

Resim 2: 17. Yüzyıla ait Yakut yerleşimi ve Kullatı nehrinin görünüşü. M. Nosov. (https://www.yakutskhistory.net/)

\footnotetext{
${ }^{55}$ A. Reşetnikov, A. Gudkov, Vliyaniye russkoy stroitelnoy kulturı na traditsionnuyu arhitekturu naroda Saha v XVIIXVIII vv., Vestnik TGASU, Cilt 21, No. 2, 2019, s. 48.
} 
Bununla birlikte Büyük Boyar Dağ kaya resimlerinde de bazı Hun dönemi konutlarının betimlendiği görülmektedir. Büyük Boyar Dağ kaya resimleri Hakasya'nın Troitsk köyünden 6 $\mathrm{km}$ mesafede bulunan Küçük Boyar Dağ kaya resimlerinden $400 \mathrm{~m}$ uzaklıktadır. Yaklaşık 9,80 $\mathrm{m}$ uzunluğunda ve 1,50 m genişliğindeki Büyük Boyar Dağ kaya resimleri birkaç şerit halinde betimlenmiştir. Betimlemelerde öncelikle evler, kazanlar ve diğer mutfak gereçleri, insan figürleri, koç, teke, boğa gibi hayvan figürleri ve tanımlanamayan bazı nesneler (Çiz. 14, 15) bulunmaktadır. ${ }^{56}$ Betimlemelerde ilginç şekilde hayvan figürleri profilden ve daha detaylı, insan figürleri ise cepheden ve daha şematik tasvir edilmiştir. Gerek hayvan gerekse insan figürlerinde derin gözleme dayanan izlenim ve yaşantıların izleri hissedilmekle birlikte tüm figürler hareket ediyormuş̧̧asına canlı tasvir edilmiştir. Büyük Boyar Dağ kaya resimlerinin tamamı dikkate alındığında adeta bütüncül tek bir kompozisyon şeklinde resmedildikleri söylenebilir. ${ }^{57}$

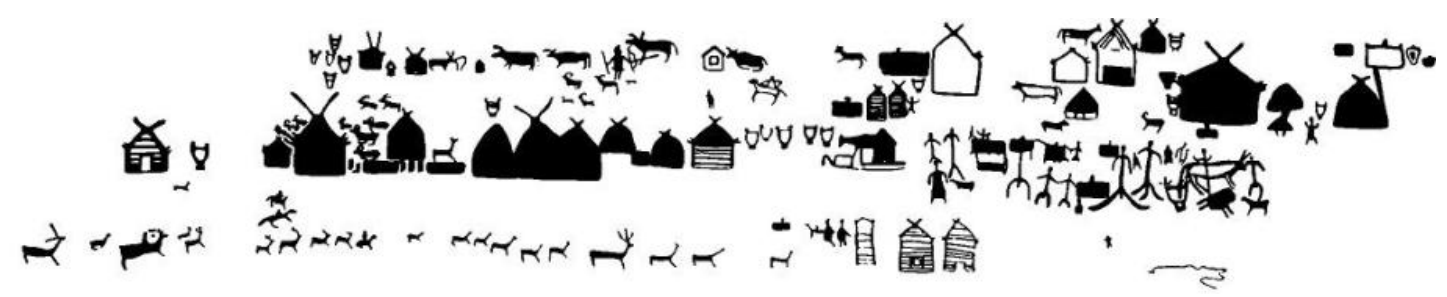

Çizim 14: Büyük Boyar kaya resimleri, (M. Devlet, 1976, Tablo V. s. 25)

HISTORY STUDIES

2471

Volume 12

Issue 5

October

2020

Üst üste konumlanan şeritlerden oluşan kompozisyonun her şeridinde oranlara dikkat edilmiştir. Konumu daha uzakta olduğu hayal edilen nesnelerin üst şeritlere ve daha yakında olması düşünülen figürlerin alt şeritlerde resmedilmesinden dolayı perspektif benzeri bir etki oluşturulmuştur (Çizim 14, 15,16). Sağdan sola bakıldığında orta şeritte bulunan bazı figürlerin söz konusu düzene uymadığı görülmektedir. Özellikle bu kısımda bazı çizimler rastgele konumlandırılmış̧̧asına üst üste binmekte, ölçek ve oran yönünden uyumsuzluklar gözlenmektedir. $^{58}$

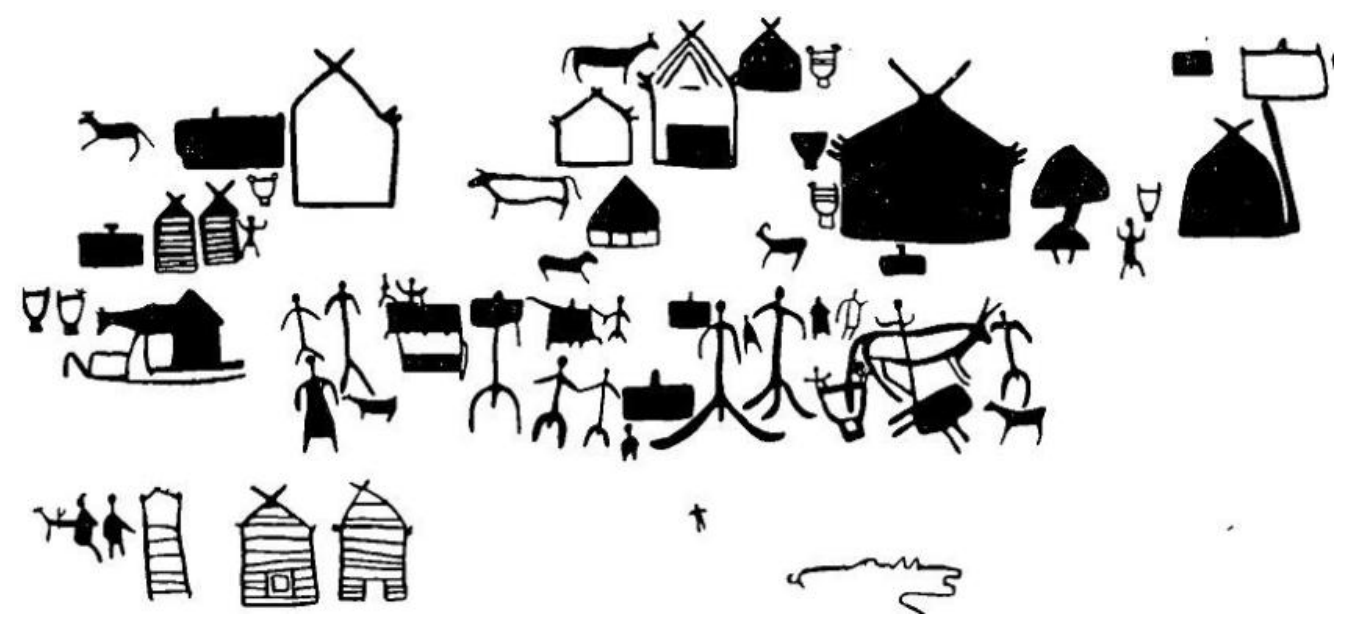

Çizim 15: Büyük Boyar Kaya resimleri. (M. Devlet)

M. Devlet'e göre Büyük Boyar Dağ kaya resimlerinde iki tip konut betimlenmektedir. Birinci tip, tomruklardan inşa edilen ahşap evler, ikinci tip ise yurt tipi çadırlardır. ${ }^{59}$ Ancak kaya

\footnotetext{
${ }^{56}$ M. Devlet, Rock engravings in the middle Yenisey Basin, Nauka, Moskva, 1976, s. 14.

57 age, s. 15.

58 age, s. 15-16.

59 age, s. 17.
} 
resimlerinin üst sağ şeridinde birbirine bir koridorla bağlanan, girişi bulunan ve çukur barınak olarak tanımlanabilecek iki yuvarlak hatlara sahip üçgenimsi yapılar ve yine aynı hizada fakat daha solda çatısı beden duvarlarından daha yüksekte resmedilen başka bir yapı daha mevcuttur (Çizim 15). Bu yüzden burada sadece iki konut tipinden ziyade daha fazla sayıda ve oldukça karmaşık mimari özelliklere sahip yapıların bulunduğunu söylemek mümkündür.

Ayrıca bazı konutların betimlemelerinde çatıların üzerinde hafifçe yükseltilmiş ve tütek açıklığına işaret eden bir unsur bulunmaktadır. Aynı yükselti çadır olduğu düşünülen yapılar için de geçerlidir. Bundan dolayı M. Gryaznov'un belirttiği gibi M. Devlet'in çadır olarak tanımladığı yapıların aslında konut olduğu doğrulanmakta ve ahşap piramidal tütekli örtüye sahip olduğu anlaşılmaktadır. Örtünün tepesinde bulunan V biçimli çıkıntıların ise örtüyü sabitlemek üzere dıştan çakılmış veya bağlanmış ahşap unsurlar olabileceği düşünülmektedir. Bununla birlikte, söz konusu konutların örtülerinde çatal gibi yükselen unsurların bir çadırda kullanılmasına ihtiyaç yoktur. İplerle sarılarak sabitlenen keçe örtülü çadırların tepesinde "baca" gibi hafifçe yükselen unsura da ihtiyaç duyulmamaktadır

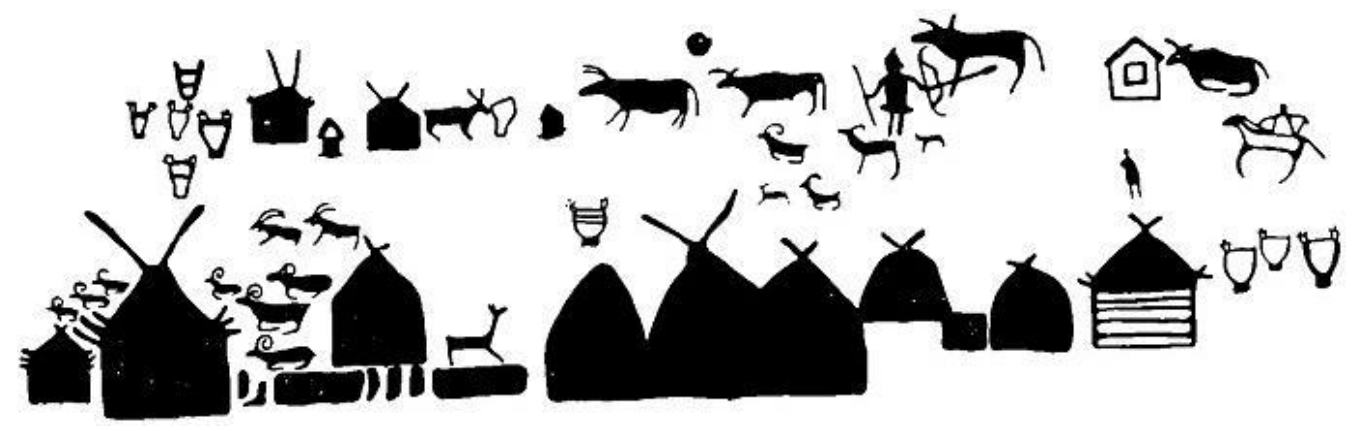

Çizim 16: Büyük Boyar Kaya resimi. (M. Devlet)

Boyar Dağ kaya resimlerinin tarihlendirilmesi konusunda M. Devlet, Hun döneminde yaygın olan ve neredeyse insan boyuna ulaşan güçlendirilmiş bileşik yay, hem Tagar hem de Taştık döneminde yaygınlık gösteren Hun tipi olarak tanımlanan ritüel kazanlarından ve başı hafifçe yukarı kalkmış, ayakları gövde altında bükülmüş kıvrık boynuzlu dağ koyunu (Argali, Kazakça Arkar) figürlerinin İskit hayvan tasvirli üslubunun karakteristiğini yansıtmasından dolayı M.Ö. 2.-1. yüzyılların ortasına ${ }^{60}$ ve daha sonraki çalışmasında ise M.S. I. yüzyıla tarihlemiştir ${ }^{61}$.

Proto-Türk halklarının konut mimarisi üzerine araştırma yapan İgor L. Kızlasov da Boyar Dağ'daki kaya resimlerinde betimlenen konutların ahşap tütekli örtüsü olduğu fikrine katılmaktadır. Ayrıca konutların çatılarındaki yukarıya taşıntıyı, İskit dönemi düz çatılı defin odalarına nazaran Tagar'dan Taştık kültürüne geçiş dönemi olarak kabul edilen Tes evresine tarihlemektedir ve bu özelliğin ilk olarak M.Ö. 2.-1. yy. arasına tarihlenen Tuyım Kurganlarındaki defin odalarının örtülerinde görülmeye başladığını belirtmektedir. ${ }^{62}$ Sonuçta M. Devlet ve İ. Kızılasov'un tarihlendirmeleri birbirini teyit etmektedir.

Kaya resimlerindeki dağ koyunu (arkar, argali) dışındaki diğer hayvan figürlerinin betimlenme şekli ve detaylarının İskit hayvan tasvirli üslubundan farklı olması ve özellikle Hun döneminde yaygınlık kazanan dörtnala koşan hayvan ikonografisi nedeniyle söz konusu kaya resimlerinin Hun dönemine ait olduğu doğrulanmaktadır. Ancak yine de bazı İskit-Saka üslup özelliklerinin hala varlığını sürdürmekte oluşu tarihlendirmenin daha erken olmasını

${ }^{60}$ M. Devlet,“Bolshaya Boyarskaya pisanitsa”, Sovetskaya arheologiya, 1965, Say1 3, s. 124-142.

${ }^{61}$ M. Devlet,1976,s. 16.

62 İgor L. Kizlasov, Pratyurkskiye jilişa. Obsledovaniye Sayano-Altayskih drevnostey, Moskva-Samara, 2005, s. 43. 
gerektirirken kompozisyonda perspektif düşüncesine yakın bir düzen gözlenmesi daha geç dönemlere tarihlendirilmesi gerektiğini düşündürmektedir. Genel bir değerlendirmeyle bu kaya resimlerinin M.Ö. 1.-M.S. 1. yüzyıllar arasına tarihlenmesi daha uygundur.

İgor Kızlasov'a göre Sibirya bölgesinde (Sayan-Altay dağları) Proto-Türk, Hun, Göktürk, Uygur, Kırgız Kağanlıkları dönemlerinde en yaygın olan ev tipi tütekli örtüye sahip tomruklardan inşa edilen ahşap evlerdir. ${ }^{63} \mathrm{Bu}$ konut tipi zamanla geleneksel bir niteliğe kavuşmuştur; hatta günümüzde dahi Sibirya'da en çok inşa edilen konut tipidir. İ. Kızlasov, Altay-Sayan dağları civarındaki bölgede saptanan kurganların ve defin odalarının mimarisini inceleyerek piramidal tütekli örtünün bölgede Taştık Kültürü'nden (Hun dönemi) itibaren varlık gösterdiği sonucuna ulaşmıştır. ${ }^{64}$ Kazı çalışmalarında Hun dönemine ait Şestakov yerleşiminde kare planlı konutlar ve Mihailovsk (Rusya Fed., Altay Kray'ında) yerleşiminde 75 adet çokgen planlı konut kalıntılarında ahşap tütekli örtü özelliğinin varlığı saptanmıştır. Ayrıca aynı özelliklere sahip konut kalıntıları Mihailovsk II yerleşiminde de tespit edilmiştir. ${ }^{65}$ Kızlasov yaptığı araştırmaların sonucunda Sibirya'da Proto-Türk ve Türk halklarına ait konut mimarisinin gelişim aşamalarını belirlemeye çalışmıştır. Elde ettiği verileri bir çizime dönüştürerek yayınlamıştır (Çiz. 17). Bu çizimlerde konutların girişleri belirtilmemiş ancak konutların merkezinde ocak bulunduğu gösterilmiştir. Çizimi yapılan altı tip konutun ortak özelliği ahşap tütekli örtüye sahip olmalarıdır.

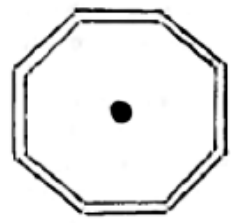

4

Volume 12

Issue 5

October

2020
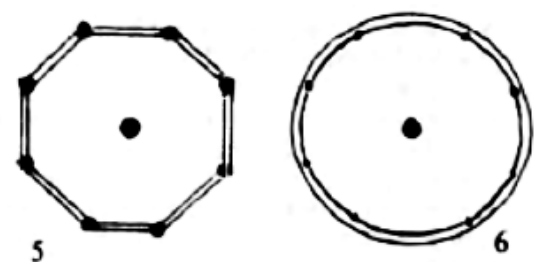

Çizim 17: Sibirya'da Proto-Türk ve Türk halklarının geleneksel konut mimarisinin gelişim aşamaları. (İ.L.Kızlasov, 2005, 59).

1) dairesel planlt toprak ev

2) dișl sivayla yalitılan ă̆ac dallarıyla örülü ev

3) çift duvarll saman dolgulu ev

4) yı̆̆ma kütük ev

5) tomruk direkli çokgen planlı ev

6) yurt çadırl.

(2-3-4-5-6 nolu konutlar etnografik örneklerle destekli)

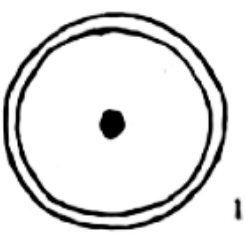

Sibirya'daki Türk halklarının geleneksel konutları, yığma veya bindirme tekniğiyle üst üste bindirilen ve yatay olarak 5-15 sıra (genellikle 8-10 sıra) kalas veya tomruklarla inşa edilen beden duvarlarına sahiptir (Çiz. 18). Kalas veya tomruklar genellikle kertme boğaz veya karaboğaz

${ }^{63}$ age, s. 42, 50, 51.

${ }^{64}$ age, s. 55

${ }^{65}$ age, s. 44-46. 
Orta Asya'da Tütekli (Kırlangıç) Örtünün Kökeni ve Tarihî Gelişim Aşamaları Üzerine bir Değerlendirme

geçme teknikleriyle birbirine bağlanmaktadır. Dıştan insan boyuna ulaşan beden duvarlarının üzerinde yukarıya doğru daralan piramidal ahșap örtü yükselmektedir ve ahşap tütekli örtü kare kesitli bir açıklıkla son bulmaktadır. Genellikle konutun tabanından tütekli açıklığa kadar yüksekliği 3,00-3,50 metreye ulaşmaktadır. Bazı konutlar plan farklılıkları göstermekle birlikte çoğunluğu kare, altıgen, sekizgen, ongen, onikigen ve ondörtgen veya dairesel planlıdır. Çokgen planlı konutların en yaygın olanı çap 1 7-8 metreye ulaşan altıgen veya sekizgen planlı konutlardır. Piramidal örtünün köşe sayıları da konutun planıyla uyumludur. Bu tür piramidal tütekli örtüye sahip evlere Hakas Türkçesinde $i b$ (ev) veya agas ib (ağaç ev) (Foto. 6) ve Şor Türkçesinde ail (ağ1l) (Foto. 7) denmektedir. ${ }^{66}$
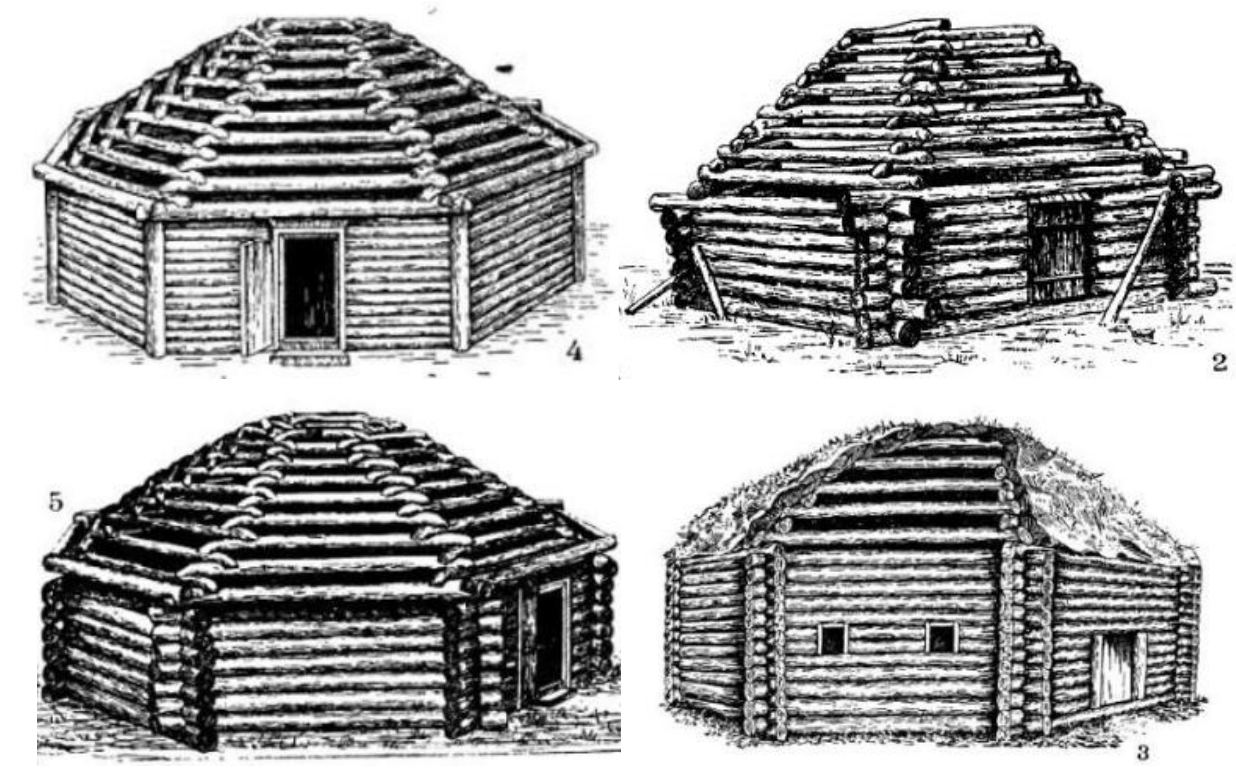

Çizim 18: Sibirya Türklerinde Piramidal tütekli örtülü geleneksel evler: Sagay Türkleri evi, Kızıl Türkleri evi, Hakas Türkleri evi, Saha (Yakut) Türklerinin evi ${ }^{67}$

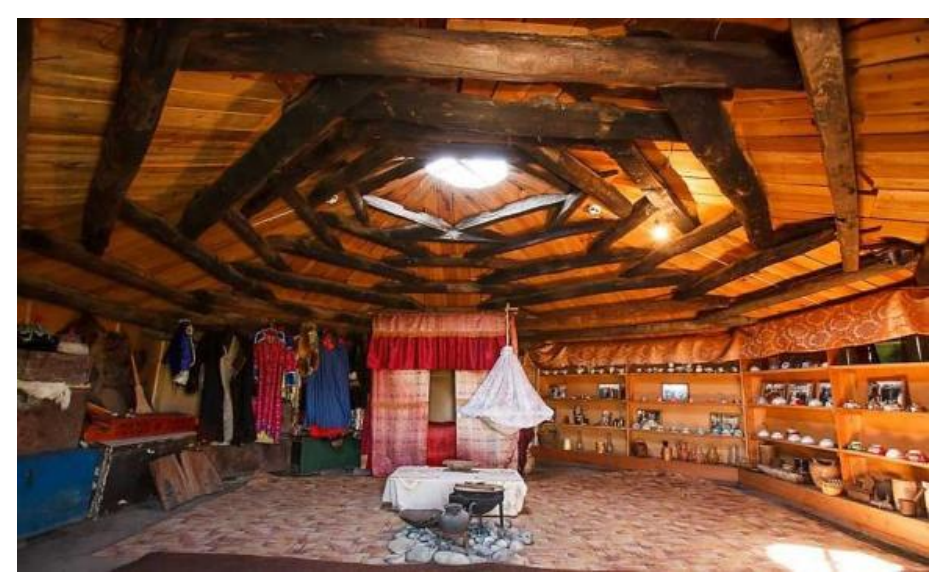

Fotoğraf 6: L. R. Kızlasov adındaki Hakasya Milli Müzesi. Agas İb (Agaç Ev) rekonstrüksiyonu ${ }^{68}$.

\footnotetext{
${ }^{66}$ age, s. 33-36.

${ }^{67}$ A. Popov, "Jilişe", İstoriko-etnografiçeskiy atlas Sibiri, Moskva-Leningrad, 1961, s. 216-219.

${ }^{68} \mathrm{https://kgcode.akipress.org/unews/un \_ post:8210}$
} 


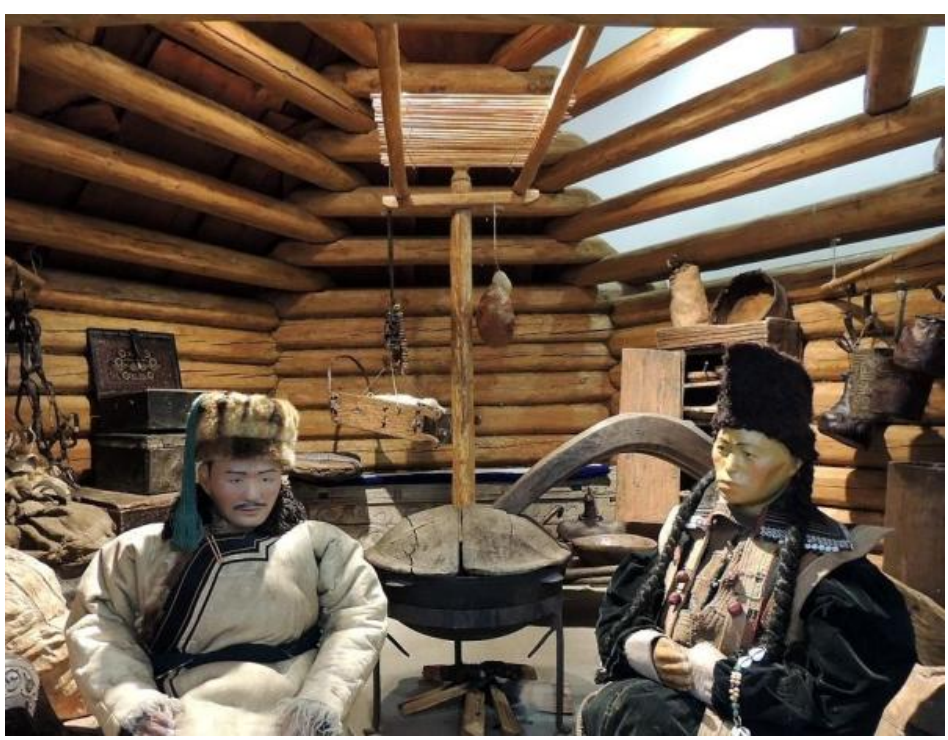

Fotoğraf 7: A. Anohin Altay Milli Müzesi, Geleneksel ahşap Ail evi rekonstrüksiyonu. ${ }^{69}$

\section{VI.5. Kanglı Döneminde Tütekli Örtü}

İç Asya'da Hun dönemi sonrasında da ahşap tütekli örtü örnekleri görülmeye devam etmiştir. Örneğin, arkeolojik araştırmalarda Güney Kazakistan'da ve özellikle Sirderya boyunda Kanglı Türklerine ait çok sayıda şehir ve yerleşim merkezi tespit edilmiştir. Söz konusu şehir ve yerleşim merkezleri Kauınç ${ }^{70}$, Otrar-Karatau ${ }^{71}$, Jetı-Asar ${ }^{72}$ kültürlerine ait olup M.Ö. 3.-M.S. 8. yüzyılın başlarına tarihlenmektedir. Hun döneminden Göktürk dönemine kadar Sirderya havzasına hâkim olan Kanglı Türkleri de ahşap tütekli örtüye sahip konut geleneğini sürdürmüştür. Örneğin, Kanglılara ait Otrar vahasındaki Kök-Mardan, Küyik-Mardan, Türkistan vahasındaki Kültöbe ve Taşkent vahasındaki Aktöbe ve Çardara yerleşimlerinde yoğunlaşarak mahalleler oluşturan çok sayıda tek odalı, iki odalı, üç odalı küçük evler ve çok odalı geniş konutlar (köşkler) saptanmıştır. $\mathrm{Bu}$ evlerin zeminlerinde açık ocaklar ve duvarların etrafında zeminden hafif yükseltilmiş sekiler bulunmuştur (Çiz. 19). Yapıların örtüleri ise ahşap malzemeden inşa edilmiş olup ocaklarının üzerinde duman çıkışı ve aydınlatmayı sağlayan tütekli örtüler yer almaktadır. Ayrıca kazılarda örtüyü destekleyen dört adet direklere ait izler konut zemininde çukurlar şeklinde tespit edilmiştir 73.

${ }^{69} \mathrm{http://xn--80aakae1am0d.xn--p1ai/photogallery/822/4853}$

${ }^{70}$ Grigoryev G., Kaunçi-Tepe, (Raskopki 1935g.) Taşkent, 1940.

${ }^{71}$ Kemal Akişev, Karl Baypakov, L. Erzakoviç, Drevniy Otrar, Moskva, 1972

${ }^{72}$ S. Tolstov , Po Drevnim deltam Oksa i Yaksarta , Moskva, 1962., L. Levina , Keramika Nijney i Sredney Sirdarii v I. tısıçeletii do naşey erı. Moskva, 1971

${ }^{73}$ Karl Baypakov, Drevnyaya i srednevekovaya urbanizaciya Kazahstana (po materiyalam issledovaniy YujnoKazahstanskoy kompleksnoy arheologiçeskoy eksdepitsii), Almatı, 2012, Cilt 1., s.375-376. 


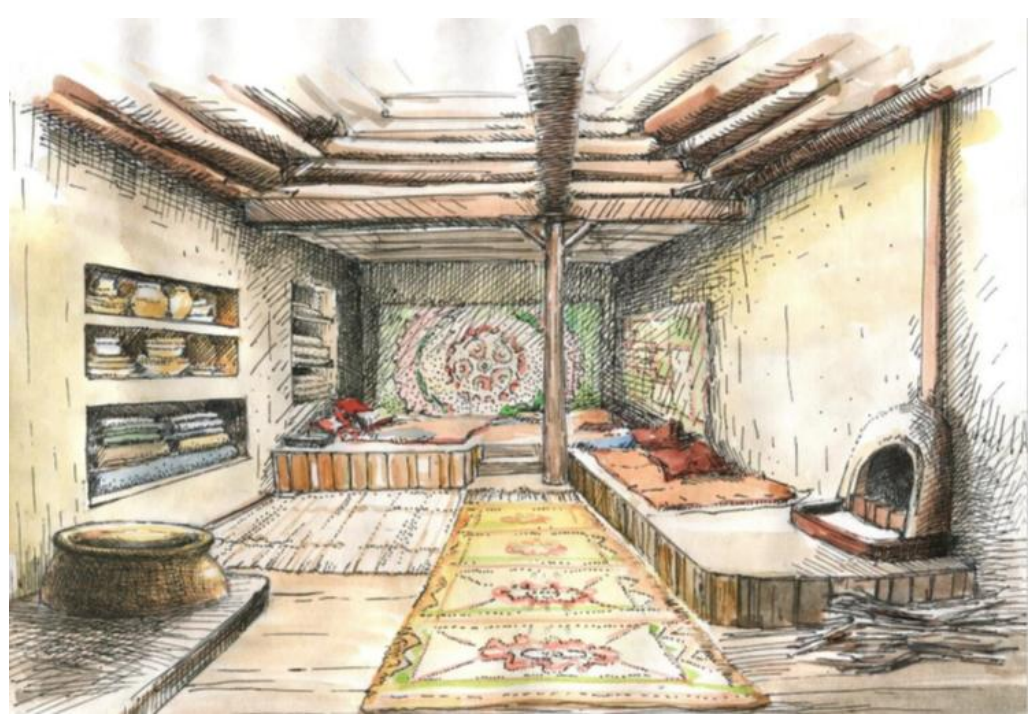

Çizim: 19: Kök-Mardan evinin iç düzeni (6.-7. yy.). A. Naurıbbayeva. ${ }^{74}$

VII.6. Göktürk Döneminde Tütekli Örtü

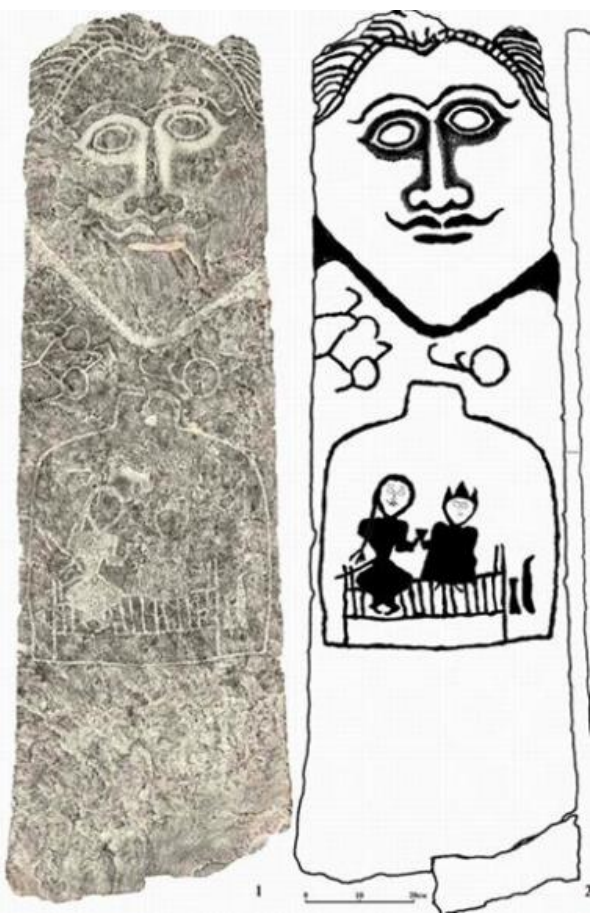

Fotoğraf 8: Koğalı Vadisinde 2 nolu bediz

Çizim 20: 2 nolu bedizin çizimi

İç Asya'da Göktürk, Türgiş ve Karluk Kağanlıkları dönemlerinde geleneksel olma özelliğini koruyan ve yaygınlık gösteren konut mimarisinin vazgeçilmezi yine ahşap tütekli örtü

74 A. Naurızbayeva, Sintez predmetno-prostranstvennoy sredi:prikladnoya isskustvo i jiloy interyer $\mathrm{v}$ istorri Kazahstana, Kazahskaya natsionalnaya akademiya isskustv im. T. Jurgenova, Almat1, 2018.

ume 12

Issue 5

October

2020 
uygulaması olmaya devam etmiştir. Bu düşünceyi doğrulayan unsurlar arasında çeşitli bölgelere yayılmış kaya resimleri ve Türk bedizleri (heykel) de sayılabilir.

2007 yılında A. Rogozhinsky tarafından Kazakistan'ın Yedisu bölgesinde Çu-İli nehirleri arasındaki Anırakay Dağı ve Sarıbulak Çayının yakınlarındaki Kogalı Vadisi'nde bir anıt mezar kompleksi saptanmıștır. Anıt mezar kompleksi bir grup kurgan, antropomorfik bedizler, balballar, törensel taş çitler ve kaya resimleri gibi öğelerden oluşmaktadır. Bunlardan 2. Nolu bediz üzerinde bir konut tasviri bulunmaktadır. 2 nolu bediz, yeşilimtrak renkte dikdörtgen biçimli ve boyu $1,62 \mathrm{~m}$, eni aşağından $0,52 \mathrm{~m}$ yukarıdan $0,46 \mathrm{~m}$ genişliği ise aşağıdan $0,15 \mathrm{~m}$ yukarıdan 0,13 m ölçülerine sahip bir heykeldir (Foto. 8). Bedizin üst kısmında kazıma tekniğiyle bir erkek yüzü betimlenmiştir (Çiz. 20). Orta kısımda ise çokgen veya dairesel planlı ve ahşap tütekli örtüye sahip bir ev tasvir edilmiştir. Evin içinde oldukça geniş bir taht üzerine oturmuş bir erkek ve bir kadın figürü bulunmaktadır. Kağan ve Katun olarak tanımlanan her iki figür de aralarında bulunan bir ant kadehini tutmaktadır. Göktürk dönemi kağan figürlerinin ayırt edici özelliklerinde olduğu gibi bağdaş kurarak oturmuş, belinde asılı k1lıcıyla uzun ve örgülü saçlı olarak tasvir edilmiştir. Katun ise taht üzerinde oturmuş, başında sivri uçları bulunan tacıyla Kağan'a ant kadehi sunarken betimlenmiştir. Her iki figürün de yüzü cepheden verilmiştir. Ayrıca bedizin üzerinde birkaç adet Türk boy veya hanedan tamgası işlenmiştir. ${ }^{75}$ Görüldüğü kadarıyla bedizin sağında üç adet bitişik ve ortasında bir tane olmak üzere dört tamga bulunmaktadır. Bunlardan sağdaki üç tamganın ortada olanı Göktürk hanedanını sembolize eden Dağ Tekesi tamgasıdır. Bu bedizin tarihlendirilmesinde dönemin sikkelerinden yararlanılmıştır. Elleriyle ant kadehi tutan Aşina boyundan Kağan ve Aşide boyundan olan Katun ikonografisi, özellikle Çaç (Taşkent) sikkelerinden çok iyi bilinmektedir. Bu dönem sikkelerin uzmanı olan Gaybullah Babayar'ın tarihlendirmesine göre sikkelerin lejantındaki Kağan, Kağan-Yabgu ve Yabgu unvanlarından Türgiş dönemine, yani 560- 630 yılları arasına tarihlendirilmektedir. ${ }^{76} \mathrm{Bu}$

Volume 12

Issue 5

October

2020

ikonografik kompozisyonun tarihlenmesinden hareketle 2 nolu bediz 6.-7. yüzyllara tarihlendirilebilir.

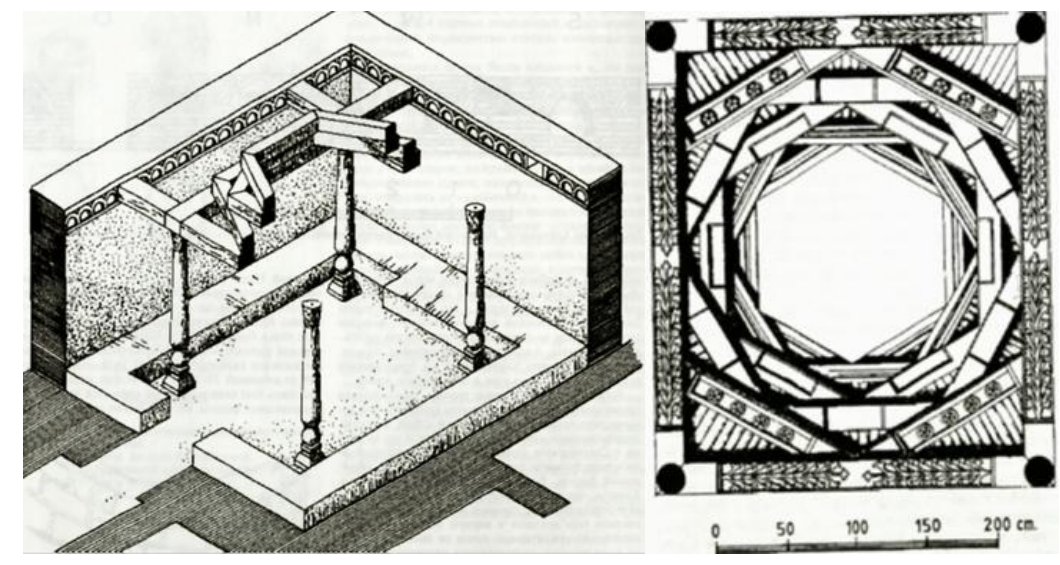

Çizim 21: Pencikent 41n. Salonun örtü restitüsyonu, Çizim 22: Urtakurgan sarayı örtü restitüsyonu, S.

Hmelnitsky, 2002

Ahşap tütekli örtünün Kazakistan dışında Orta Asya'nın güney bölgelerine Özbekistan ve Tacikistan'a yayılması ise daha geç dönemlerde gerçekleşmiştir. Bunda yörenin iklim

\footnotetext{
75 A. Rogozhinsky, Novie nahodki pamyatnikov Drevnetyurkskoy epigrafiki i monumentalnogo iskusstva na Yuge i Vostoke Kazahstana. Rol nomadov v formirovanii kulturnogo naslediya Kazahstana, Nauçnıe çteniye pamyati N. Masanova, Almat1, 2010, s. 335-342.

${ }^{76}$ Gaybullah Babayarov, "Çaç v epohu Turkskogo Kaganata (po numismatiçeskim dannım)", İstoriya Uzbekistan'a $i$ arheologiçeskih i pismennıh istoçnikah. Taşkent, 2005, s. 197-207.
} 
özelliklerinin yanısıra ahşap malzeme yönünden kaynakların az olmasının etkisi yadsınamaz. Bununla birlikte Özbekistan ve Tacikistan'da arkeolojik verilere göre en erken tarihli ahşap tütekli örtü örneği M.S. 6. yüzyıl öncesine tarihlenmemektedir. Taşkent vahasının şehirleşmesi üzerine kazı ve araştırmalar yapan Yuri Buryakov 6.-8. yy. tarihlenen Minguyruk arkeolojik kompleksine ait Minguyruk, Hanabad, Kanka, İmlak gibi 32 şehri ve Aktepe, Çılanzar, Aktepe Yunusabad gibi 292 yerleşimi inceledikten sonra yapıların örtülerinde "ruzan" veya ahşap tütekli örtülerin Göktürk döneminde yaygınlık kazandığını belirtmiştir ${ }^{77}$. Tacikistan coğrafyasında ise ahşap tütekli örtünün görülmeye başlaması 6. yüzyıla tarihlenen Pencikent ve Urtakurgan sarayları ile ilgilidir ${ }^{78}$. Ahşap tütekli örtü uygulamasının Özbekistan ve Tacikistan coğrafyalarında görülmeye başlaması büyük olasılıkla bölgenin Göktürk, Batı Göktürk ve Türgiş Kağanlıklarının hâkimiyetine girmesiyle ilgilidir. Ancak Ortaçağ'da Özbekistan ve Tacikistan coğrafyalarında saray, kössk ve konut mimarisinde karşımıza çıkan dikkat çeken ahşap tütekli örtü örnekleri bilinmektedirler. Örneğin, 5.-8. yüzyıllar arasında Göktürk ve Türgiş dönemine tarihlenen Pencikent'teki sarayın 41 nolu kabul salonunun merkezinde konumlandırılan dört adet ahşap direkle taşınan ahşap tütekli örtü sisteminin varlığı tespit edilmiştir (Çiz. 21). ${ }^{79}$

Ayrıca diğer bir örnek ise Tacikistan coğrafyasında 8. yüzyıla Türgiş dönemine tarihlenen ahşap tütekli örtüye sahip Urtakurgan sarayıdır. S. Hmelnitsky’ye göre altı adet ahşap kareden oluşturulan ve birbiri üzerine 45 derecelik açıyla konumlandırılan ve yukarıya doğru daraltılan ahşap tütekli örtü bulunmaktadır (Çiz. 22). ${ }^{80}$

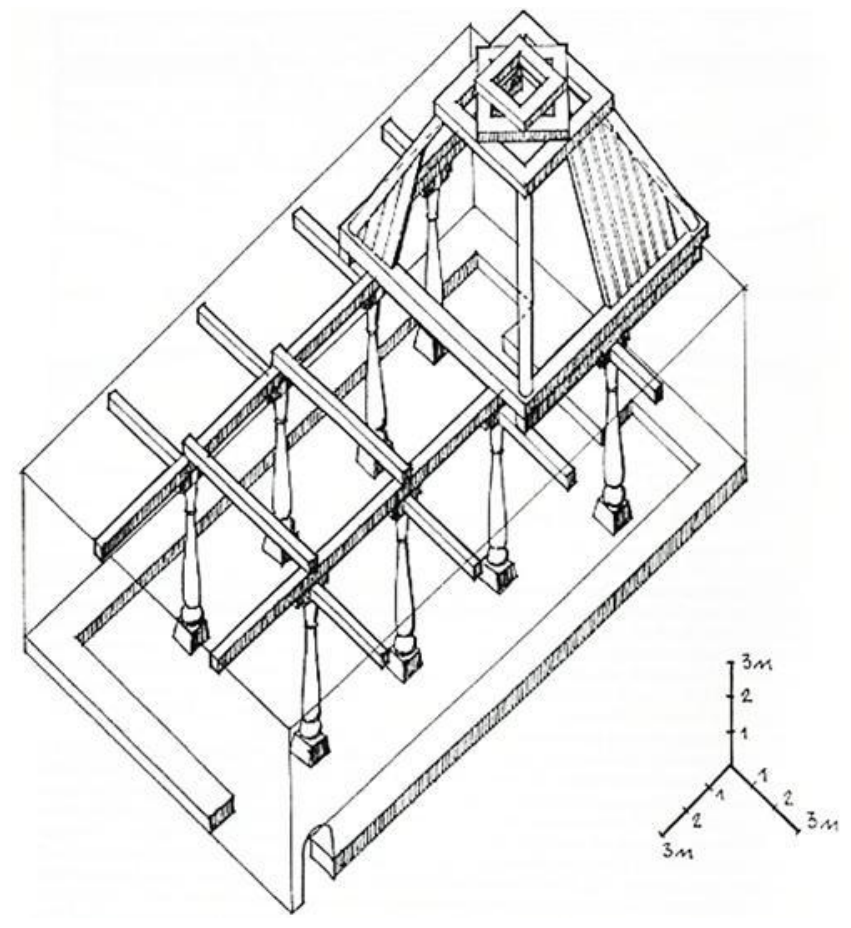

Çizim 23: Varahşa Sarayındaki Mavi Salonun Tütekli Örtü Restitüsyonu (Marşak, 2000)

\footnotetext{
${ }^{77}$ Yu. Buryakov, Genezis i Etapı razvitiya gorodskoy kulturı Taşkentskogo Oazisa, Fan yayınevi, Taşkent, 1982, s. $80-81$

${ }^{78}$ S. Hmelnitsky, Mejdu Kuşanami i Arabami, Arhitektura Sredney Azii v V-VIII. veke, Gamajun, Berlin-Riga, 2002, s. $46-47,116$

${ }^{79}$ age, s. 46.

${ }^{80}$ M. Mamadnazaro, Pamyatniki zodçestva Tacikisitana, Moskva: Progress-Traditsiya, 2015, s. 271
} 
Bununla birlikte Varahşa (7.-8. yy.) şehrinde bulunan Buhar-Hudat Sarayının Kızıl Salonunun $^{81}$ ve Mavi Salonunun ahşap tütekli örtüye sahip olduğu anlaşılmıştır. ${ }^{82}$ (Çiz. 23) Ayrıca Özbekistan'ın Surhanderya vilayetinde bulunan Balalık Tepe (6. - 7. yy.) Sarayı'nda 14 nolu kare planlı mekanda ahşap tütekli örtü bulunduğu ortaya konulmuştur ${ }^{83}$

Bu sarayların dışında Göktürk ve Türgiş dönemlerinde Güney Kazakistan'da ahşap tütekli örtünün gerek saray ve köşklerde gerekse geleneksel konut mimarisinde uygulanmaya devam edildiği görülmüştür. Örneğin, Arıs nehrinin Sirderya'yla birleştiği bölgede Otrar-Farab vahasında 1981 yılında K. Akişev ve K. Baypakov tarafindan yürütülen kapsamlı kazılar sonucunda Kuyruktöbe'nin şehristan bölümünün doğu kısmında 7.-8. yüzyıllara tarihlenen büyük bir köşk ortaya çıkarılmıştır. Kazı verilerine göre köşkün merkezî salonunda ahşap tütekli örtü tespit edilmiş (Çiz. 24) ve ahşap örtüyü taşıyan dört adet ahşap direğe ait temeller ve izlere rastlanılmıştır. ${ }^{84}$

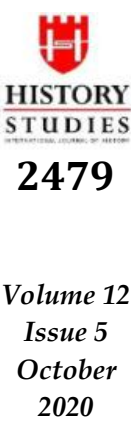

2020

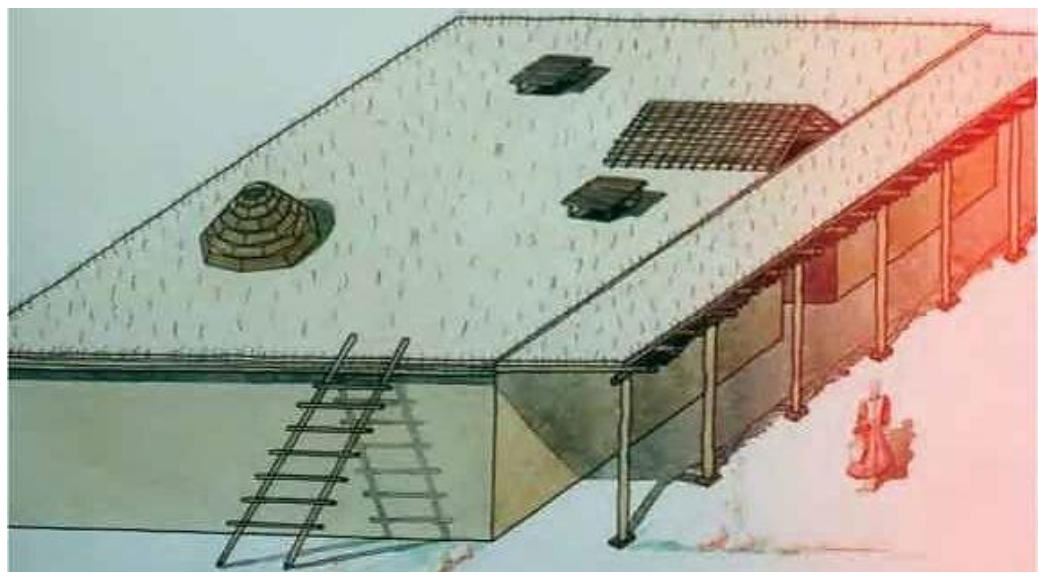

Çizim 24: Kuyruktöbe’de ahşap tütekli örtülü konutun restitüsyonu (Baypakov,2012, t. 58)

Bununla birlikte Kuyruktöbe'de yaklaşı 80x80 m. ölçülerindeki kare planlı İç Kale Sarayının (7.-9. yy.) 10,50 x 15 m büyüklüğündeki merkezi kabul salonunun da ahşap tütekli örtülü olduğu tespit edilmiştir (Çiz. 25, 26). ${ }^{85}$

\footnotetext{
${ }^{81}$ V. Şişkin, Varahşa, İzdatelstvo Akademii Nauk SSSR, Moskva,1963, s. 58.

82 B. I. Marşak, "The Ceilings of the Varakhsha Palace" Parthica 2. Incontri di culture nel mondo antico. Istituti editoriali e poligrafici internazionali, Pisa-Rome, 2000, s. 153-167.

${ }^{83}$ L. Albaum, Balalıktepe, Taşkent:İzdatelstvo Akademii Nauk UzSSR, 1960, s. 87.

${ }^{84}$ Karl Baypakov, Gorodişe Kuyruktöbe - Gorod Keder, Almatı, 2005 s. 63-64;

${ }^{85}$ Karl Baypakov, G. Ternovaya, Tsentralnıy zal dvotsa gorodişa Kuyrıktöbe, Priaralye v drevnosti i srednevekovye, Moskva, 1998, s. 156-167.
} 

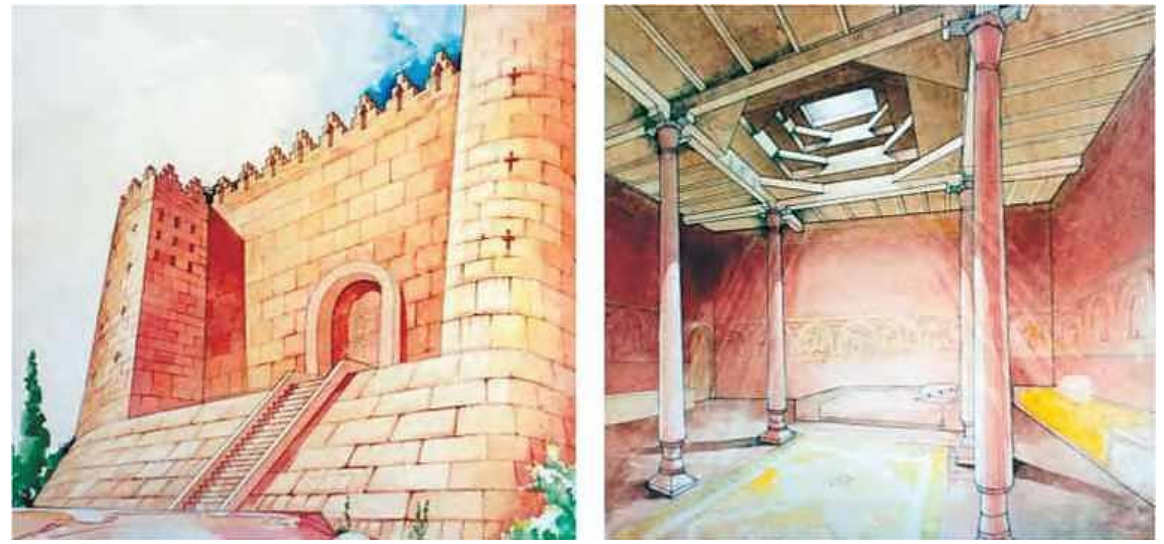

Çizim 25 ve 26: Kuyruktöbe sarayı ve merkezi salondaki ahşap tütekli örtünün restitüsyonu. K.

Baypakov.

Ayrıca, Güney Kazakistan'da Otrar vadisindeki Altıntöbe şehrinde yürütülen kazılarda 8.-9. yüzyıllara tarihlenen bir konutun 5,55 x 4,60 m ölçülerindeki merkezi mekânının ahşap tütekli örtüye sahip olduğu kanıtlanmıştır. ${ }^{86}$ Yine, Güney Kazakistan'da Türkistan Vilayetinde bulunan Şöytöbe şehrinde 7.-8. yüzy1llara tarihlenen $11 \times 7,5$ metre ölçülerinde ve ahşap tütekli örtüye sahip dikdörtgen planlı bir konut kazılarda ortaya çıkarılmıştır. ${ }^{87}$.
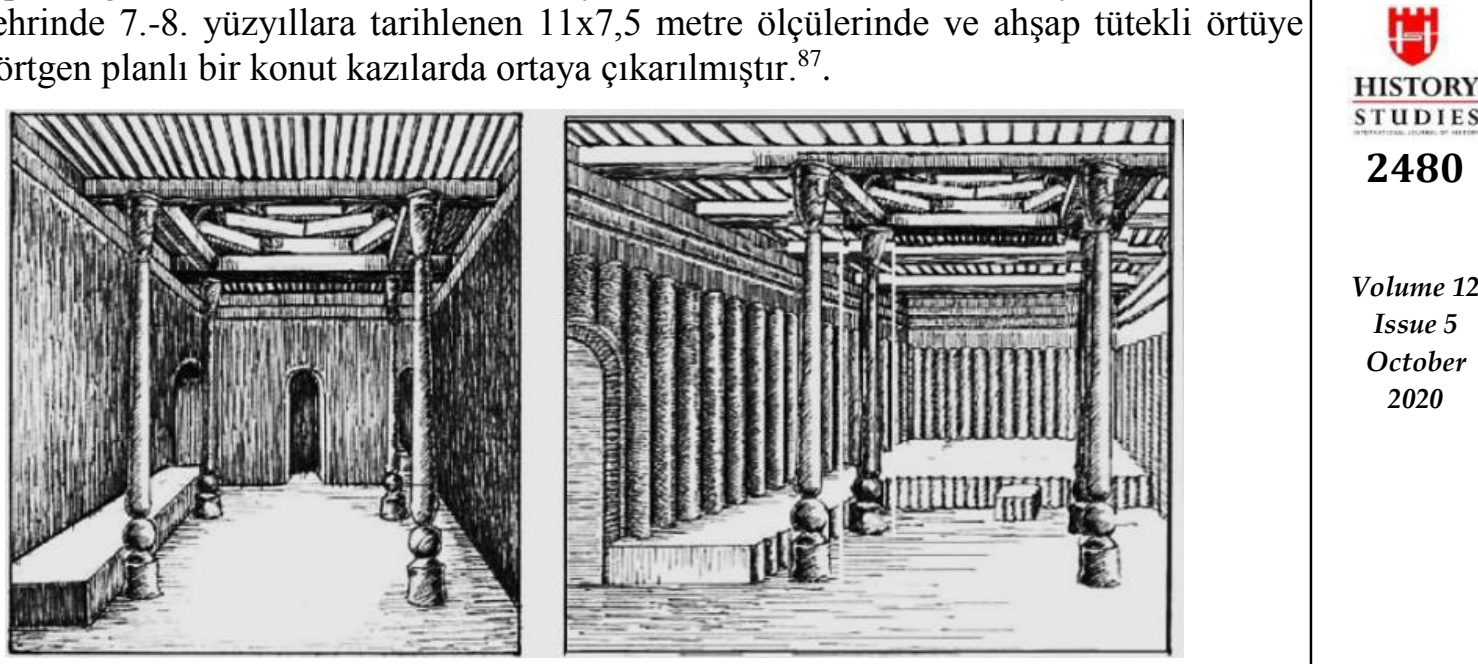

Çizim 27 ve 28: Kostöbe Sarayının restitüsyonu (Voliçenko - Almaganbetova, 2016, s.116)

Ahşap tütekli örtü sisteminin saray mimarisinde yaygın olarak kullanıldığı diğer bir örnek ise Güney Kazakistan'da Taraz şehrinin 15 km kuzeyindeki Kostöbe'de bulunmuştur. Ortaçağ'da Camukat (Hamukat) şehri olduğu düşünülen Kostöbe'de 6.-9. yüzyıllar arasına tarihlenen iç kaledeki bazı yapıların salon veya kabul salonu benzeri geniş olan mekânlarında ahşap tütekli örtü bulunduğu ve örtüyü taşıyan dörder adet direklerin temelleri kazılarda saptanmıştır (Çiz. 27, 28). ${ }^{88}$ Ayrıca Türk hükümdarlarınca yönetilen Kulan şehrinde (6.-8. yy.) 2015 yılında kazıları

\footnotetext{
${ }^{86}$ E. Smagulov, Kompleks ritualnıh atributov iz Otrarskogo oazisa, Arheologiçeskiye issledovaniya v Kazahstane, Alma-Ata, 1992, s. 34-42.

${ }^{87}$ Karl M. Baypakov, age, 2012. s. 280

${ }^{88}$ Karl Baypakov-S. Kasenov , "Raskopki Tsitadeli i Nekropoley na Gorodişe Kostöbev Talasskoy doline", News of the National Academy of Sciences of the Republic of Kazakhstan, 2014, s. 52-56..
} 
gerçekleştirilen 1 ve 2 nolu yapıların örtülerinin duman ve 1şık geçişini sağlayan tütekli ahşap örtü olduğu vurgulanmıştır. ${ }^{89}$

\section{VIII.7. Ortaçağ’dan Günümüze Tütekli Örtü}

Güney Türkistan bölgesinde 8.-9. yüzyıllardan itibaren İslam'ın yayılmasıyla birlikte ilk cami ve mescidler inşa edilmeye başlanmıştır. Bu yapıların mimarisinde İslam kültürüne ait unsurların yanı sıra bazı yerel unsurlar da etkili olmuştur. Örneğin bu döneme ait camilerin en dikkat çeken özelliklerinden biri ahşap direkli ve ahşap örtülü olmalarıdır. Ahşap örtü söz konusu olduğunda Orta Asya Türk Mimarisinin geleneğe dönüşmüş özelliklerinden biri olduğu anlaş1lmaktadır. İslami döneme ait birçok ahşap tütekli örtüye sahip yapı günümüze ulaşamamış olmasına rağmen arkeolojik veriler yeterli bilgiyi sunmaktadır. Örneğin, 9.-10. yüzyıla tarihlenen Taraz Ulu Camisi $^{90}$ (Torgoyev A.,2013, s.127-131) ve Kuyruktöbe Keder Ulu Camisi'nde ${ }^{91}$ (Hmelnitsky, 1992, s.70) ahşap tütekli örtü uygulanmıştır.

Diğer yandan ahşap tütekli örtüye sahip Kazak geleneksel konutları 20. yüzyıla kadar inşa edilmeye devam etmiştir. Bu konutlar, Botay konutları ve ahşap tütekli örtülerinin yanı sıra günümüz Sibirya halklarının geleneksel konutlarıyla büyük benzerliklere sahiptir. ${ }^{92}$
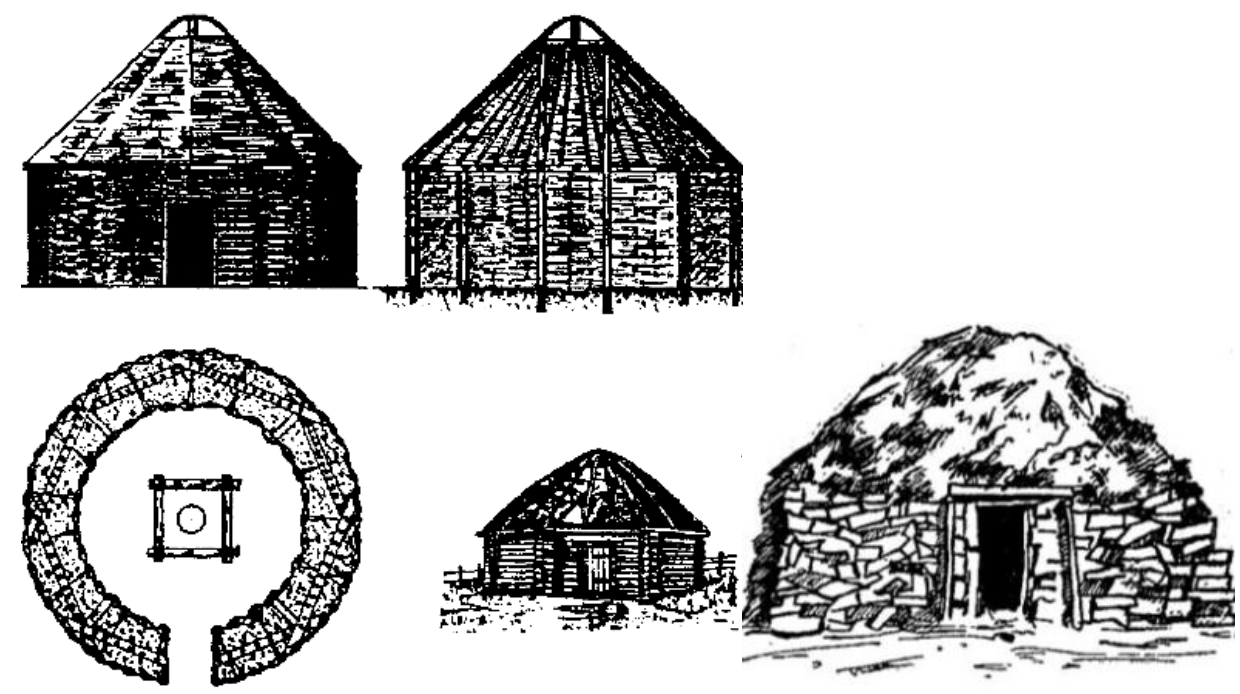

Çizim 29: Kazak geleneksel konutu "şoşala"; Çizim 30: Taş duvarlı şoşala, (A. Margulan)

Kazak topluluklarının kışlaklarında bulunan geleneksel konut mimarisinde ahşap tütekli örtüye sahip dairesel, kare veya çokgen planlı yapılara "şoşala" denmektedir (Çiz. 29). Şoşala kelimesi şoşak ve alau (şaçak/sivri ve alev) gibi iki sözcüğün birleşmesinden oluşmuştur. Şoşala'nın eş anlamlısı Orta ve Kuzey Doğu Kazakistan'da "karatam", Çu vadisi ve Karatau bölgesinde ise "moroşak" tabirleridir. Çu vadisinde et tütsüleme işlemine "morlamak" denilmesi nedeniyle moroşak sözcügünün kökeni bu söze dayandırılmaktadır (Margulan A.,2010, s.184). ${ }^{93}$ Daha çok Kazakistan'ın Çu ve Sarısu nehirleri havzalarında, Karatau ve Yedisu bölgelerinde, kuzeyde Kızıljar (Petropavlovsk), Omsk, Kökşetau, Kostanay, doğuda Tarbagatay ve Kazak

\footnotetext{
${ }^{89}$ Serik Akılbek, E. Smagulov, Sergei Yatsenko, "Dekorativnoye Ubranstvo Rezidentsii Tyurkskih Praviteley VIII veka v Tsitadeli goroda Kulan”, Evraziyanın Madeni Murası, (ejelgi dauirden bügingi künge deyin), A. Margulan atındag1 Arheologiya İnstitut1, Almat1, 2016, s. 51-63.

${ }^{90}$ A. Torgoyev, Izvestiye Natsionalnoy Akademii Respubliki Kazahstan, 2013,. Sayı 3, s. 127-131.

${ }^{91}$ Hmelnitsky, age, s.70.

${ }^{92}$ Dzhansugurova vd, agm, s. 79-80.

${ }^{93}$ Margulan, age. 2010, s. 184.
} 
Altay'ında inşa edilmiştir. Bu bölgelerin ortak özelliği ormanın ve ahşap malzemenin bol olmasıdır. Ortaçağ' da yaygınlık gösteren ahşap tütekli örtüye sahip evler geç dönemlerde mutfak veya et tütsüleme yapılarına dönüşmüştür. ${ }^{94} \mathrm{Bu}$ noktada ilginç benzerliklerden biri ise Erzurum yöresi geleneksel konutlarında ahşap tütekli örtüye sahip olan bölümlerin "tandırevi" olarak adlandırılması ve mutfak işlevinde kullanılmasıdır. ${ }^{95}$

15.-18. yy. tarihlenen Kazak kışlakları üzerine araştırma yapan Sayden Zholdasbayev'e göre ahşap tütekli örtüye sahip evlerin ve ayrı birim şeklindeki şoşalaların duvarları özellikle Güney Kazakistan, Yedisu bölgesi ve Orta Kazakistan'da taş malzemeyle inşa edilmiştir (Çiz. 30) ${ }^{96}$. Arkeolojik araştırmalar sonucunda Kazakistan'ın dağlık bölgelerindeki kışlaklarda yer alan ahşap tütekli örtüye sahip konutların yer üstünde inşa edildiği görülmüştür. Ancak nehir veya çayların yakınında bulunan kışlaklardaki konutlar ise hâkim rüzgârlardan ve olumsuz hava şartlarından korunması amacıyla çukur barınak modeline (yer evi) göre inşa edilmiştir. Bununla birlikte kışlaklardaki konutların planları ve boyutları da değişiklik göstermektedir. Yer evlerde hem dikdörtgen hem de dairesel plan görülürken toprak seviyesinde inşa edilen taş evlerde ise genellikle dairesel plan uygulanmıştır. Her iki tip konutların ortak yönü ahşap tütekli örtüleridir. Dikdörtgen planlı taş konutlar genellikle 4,00-5,00 m x 3,00-4,00 m. boyutlarına sahiptir. ${ }^{97}$ Bununla birlikte A. Margulan Kokşetau Vilayetinin Sırımbet köyünde ve Omsk Vilayetinde tamamen ahşap malzemeden inşa edilen kare ve çokgen planlı tütekli örtülü evleri fotoğraflarla belgelemiştir. ${ }^{98}$

\section{Sonuç}

Arkeolojik verilere göre bilinen ilk ahşap tütekli örtü uygulaması, Kuzey Kazakistan'da Kalkolitik (Bakır Taş Çağı) döneme tarihlenen Botay Kültürü'ne ait konutlarda tespit edilmiştir. Yerel mimarinin geleneksel bir unsuru haline gelerek günümüze kadar varlığını sürdürmüştür. Botay'da M.Ö. 3700-3500 yılları arasına tarihlenen ilk ahşap tütekli örtü örneklerinin sayıları yüzlerce konuta ulaşarak M.Ö. 1500 yıllarına kadar kesintisiz devam etmiştir. Tunç Çağından itibaren ahşap tütekli örtü Botay'dan doğu, batı ve güney yönlere doğru yayılma göstermeye başlamıştır. Tunç Çağında Andronovo kültürel birliği kavramıyla tanımlanan topluluklara yayılan ahşap tütekli örtü, Kazakistan'da özellikle Atasu, Begazı ve Dandıbay(M.Ö.12-8) ${ }^{99}$ kültürlerine tarihlenen yerleşim merkezlerinde geleneksel mimarinin vazgeçilmez karakteristik örtü uygulaması haline gelmiştir. Daha sonra İskit-Saka, Hun ve Kanglı dönemlerinde özellikle Güney Kazakistan coğrafyasında yaygın uygulandığ 1 çok sayıda örnekle tespit edilmiştir. Ortaçağ' da ise Göktürk, Türgiş ve Karluk köşk ve saraylarında anıtsal mimaride daha çok dikkat çeken ahşap tütekli örtü İlk Türk-İslam yapılarına da nüfuz etmiştir. Genellikle devasa boyutlara sahip ve kubbe ile örtülmesi neredeyse imkânsız büyüklükteki ulu camilerde ahşap direkli taşıyıcılar ve ahşap malzemeden örtü uygulamaları tercih edilmiştir. Bu noktada yer yer ahşap tütekli örtü uygulama alanı bulabilmiştir. Ortaçağ'dan 20. Yüzyılın başlarına kadar Kazak geleneksel konut mimarisinde yaygınlığını sürdüren ahşap tütekli örtü uygulamaları aynı zamanda Sibirya halklarının geleneksel konut mimarisinde ise günümüze kadar yaygınlığını korumayı başarmıştır.

\footnotetext{
${ }^{94}$ Margulan, age. 2010, s. 184.

${ }^{95}$ Zerrin Köşklü, Şerife Tali, agm, s. 97-111.

${ }^{96}$ S. Zholdasbayev, Kazak Elinin XXVIII gasırlardagı turaktı mekencaylarl, Kazak gılımi-zertteu institutının baspa tob1, Astana, 2017, s. 43-44.

${ }^{97}$ age. s. 82-83.

${ }^{98}$ Margulan, age, 2010, s. 184-185.

${ }_{99}$ Alkey Margulan, (1998). Begazı-Dandıbayevskaya Kultur Tsentralnogo Kazahstana, Almat1, İnstitut Arheologii im. A.H. Margulana, 2. Bask1, Cilt 1. s. 351-356.
} 
Orta Asya'nın güneyindeki Özbekistan ve Tacikistan'daki ahşap tütekli örtü örnekleri ise oldukça geç dönemlere aittir. Özbekistan'da ahşap tütekli örtünün Kanglı ve Göktürk dönemiyle birlikte yaygınlık kazandığı arkeolojik çalışmalar sonucu saptanmıştır. Tacikistan'da ise M.S. 6. yüzyıl öncesine tarihlenebilen herhangi bir ahşap tütekli örtü bulgusuna rastlanmamıştır. Ahşap tütekli örtünün Tacikistan coğrafyasında görülmeye başlaması da bölgenin Göktürk hâkimiyetine girmesiyle ilişkilendirilmektedir.

Ayrıca ahşap tütekli örtü uygulamasının Uralların batısında Geç Tunç Çağında yani Botay’da tespit edilen ilk ahşap tütekli örtü örneğinden yaklaşık 2400-2500 y1l sonra görüldüğü belirtilmektedir. Bu durum Kafkasya ve özellikle Güney Kafkasya bölgesinde ahşap tütekli örtülerin en erken örneklerinin Demir Çağı öncesine gidemeyeceğini gösterir.

Botay'daki konutlardan başlayarak günümüze kadar yaklaşık 5700-5500 boyunca kesintisiz devam eden ve bir geleneğe dönüşen ahşap tütekli örtü, Proto-Türk ve Türk toplulukların mimarisi ve kültür tarihi açıdan çok öneme sahiptir. Kültürel süreklilik olgusunu tam olarak ortaya koyan bu mimari gelenek, Orta Asya Türk mimarisinin ortaya çıkış ve gelişme çağları konusunu aydınlatma yolunda önemli bilgilere ulaşmamızı sağlamaktadır.

\section{Kaynakça}

AKIN, Günkut, "Tütekli Örtü Geleneği Anadolu Cami ve Tarikat Yapılarında Tüteklikli Örtü”, Vakıflar Dergisi 22, İstanbul, 1991, s. 323-354

AKILBEK, Serik - SMAGULOV, E. - YATSENKO, S., "Dekorativnoye Ubranstvo Rezidentsii Tyurkskih Praviteley VIII veka v Tsitadeli goroda Kulan", Evraziyanın Madeni Murası, (ejelgi dauirden bügingi künge deyin), A. Margulan atındag1 Arheologiya İnstitut1, Almat1, 2016, s. 51-63

Volume 12

AKIŞ̧EV, Kemal - BAYPAKOV, Karl - ERZAKOVİÇ, L., Drevniy Otrar, Moskva, 1972

ALBAUM, L., Balalıktepe, İzdatelstvo Akademii Nauk UzSSR, Taşkent, 1960,

BABAYAROV, Gaybullah, "Çaç v epohu Turkskogo Kaganata (po numismatiçeskim dannım”), İstoriya Uzbekistan 'a i arheologiçeskih i pismennı istoçnikah. Taşkent, 2005, s. 197-207

BAYPAKOV, Karl, Gorodişe Kuyruktöbe - Gorod Keder, Almatı, 2005.

BAYPAKOV, Karl, Drevnyaya i srednevekovaya urbanizaciya Kazahstana (po materiyalam issledovaniy Yujno-Kazahstanskoy kompleksnoy arheologiçeskoy eksdepitsii), A. Margulan atındag1 Arheologiya İnstitutı, Almat1, 2012.

BAYPAKOV, Karl - KASENOV, S., "Raskopki Tsitadeli i Nekropoley na Gorodişe Kostöbev Talasskoy doline", News of the National Academy of Sciences of the Republic of Kazakhstan, 2014, s. 52-56.

BAYPAKOV, Karl - TERNOVAYA, G., "Tsentralnıy zal dvotsa gorodişa Kuyrıktöbe", Priaralye v drevnosti i srednevekovye, Moskva, 1998, s. 156-167.

BEİSENOV, Arman, "Krugloye jilişe sakskoy epohi”, Samarski nauçnıy vestnik, Cilt 6, 1 (18), 2017, s. 94-100.

BURYAKOV, Yuri, Genezis i Etapı razvitiya gorodskoy kulturı Taşkentskogo Oazisa, Fan yayınevi, Taşkent, 1982.

CHOİ, Sunah, "Bindirme Tavan": Bir Adlandırma Sorunsalı" Ankara Üniversitesi Sosyal Bilimler Dergisi, 8(2), 2017, s. 195-202. 
Orta Asya'da Tütekli (Kırlangıç) Örtünün Kökeni ve Tarihî Gelişim Aşamaları Üzerine bir Değerlendirme

DAMGAARD, Peter de Barros, vd.., The first horse herders and the impact of early Bronze Age steppe expansions into Asia, Science, 360, 1422, 2018, s. 1,4

DEVLET, M., "Bolshaya Boyarskaya pisanitsa”, Sovetskaya arheologiya, 1965, Sayı 3, s. 124 142.

DEVLET, M., Rock engravings in the middle Yenisey Basin, Nauka, Moskva,1976.

DZHANSUGUROVA, L. - ZAİBERT, Viktor - KITTOV, E. , - IXAN O., - NURZHIBBEK ZHUNUSSOVA, G.,- DZHANTAEVA, K., - KUZOVLEVA, E., - KHUSSAINOVA, E., "Paleogenetic Investigation of the Human Remains of the Eneolithic Period from the settlement Botai", News of the National Academy of Sciences of the Republic of Kazakhstan, Cilt 4, Say1 322, 2017, s. 78-79.

GLAUDINOV, B., Istoriya Arhitekturı Kazahstana, KazGASA, Almat1, 1999.

GRİGORYEV, G., Kaunçi-Tepe, (Raskopki 1935g.) Taşkent, 1940

GRYAZNOV, Mikhail, "Boyarskaya pisanitsa", Problemı istorii materialnoy kulturı, No. 7-8, 1933, s. 41-45.

GRYAZNOV, Mikhail, "Vostochnoye Priaralye", Srednyaya Aziya v epohu kamnya i bronzl, Moskva-Leningrad, 1966, s. 233-238.

GRYAZNOV, Mikhail, "Zemlyanki Bronzovogo Veka bliz hutora Lyapicheva na Donu”, KSIIMK, 1953, Say1 50, s. 137-148

HMELNITSKY, S., Mejdu Kuşanami i Arabami, Arhitektura Sredney Azii v V-VIII. veke., Gamajun, Berlin-Riga, 2002.

KIZLASOV, İgor L., Pratyurkskiye jilişa. Obsledovaniye Sayano-Altayskih drevnostey, Moskva-Samara, 2005.

KİSILEV, S., Drevnaya Ístoriya Yujnoy Sibiri, Moskva, 1951.

KİSLENKO, M., "Opıt Rekonstruktsii Eneoliticheskogo Jilişa”, Problemı rekonstruktsii hozaistva $i$ tehnologiy po dannım arheologii. V. Zaybert editörlüğünde, İA NAN Respubliki Kazahstan, Petropavlovsk, 1993, s.117-136.

KİSLENKO, M., Raskopki Poseleniya Roşinskoye, Nauka, Moskva, 1984. s. 511

KÖŞKLÜ, Zerrin - TALİ, Şerife, "Geleneksel Erzurum Evlerinde Tandırevi (Mutfak) ve Mimarisi” Sanat Dergisi. sayı 11, 2007 s. 97-111

KRIVTSOVA-GRAKOVA, O., "Alexeevskkoye poseleniye i mogilnik". Trudl Gosudarstvennogo istoriçeskogo muzeya, Moskva, Say1 17., 1948, s. 57-164

KUZMINA, E., Dve linii razvitiya domostroitelnıh traditsiy v Starom Svete, Problemı Arheologii Uralo-Kazahstanskih stepey, Çelyabinsk, 1988.

LEVINA, L., Keramika Nijney i Sredney Sirdarii v I. tısıçeletii do naşey erı. Moskva, 1971.

LVOVA, E., - OKTYBRSKAYA, İ., - SAGLASOV, A., - USMANOVA M., Traditsionnoye mirovozreniye Tyurkov Yujnoy Sibiri. Veşnuy mir , Novosibirsk, 1988.

MamadnaZArov, M., Pamyatniki zodçestva Tacikisitana, Progress-Traditsiya, Moskva, 2015. 
MARGULAN, Alkey, Begazı-Dandıbayevskaya Kultur Tsentralnogo Kazahstana, İnstitut Arheologii im. A.H. Margulana, Almat1, 2. Bask1,1998.

MARGULAN, Alkey, Şıgarmaları, Alatau Bastası, Almatı,2010.

MARGULAN, Alkey - AKIŞEV, Kemal - KADIRBAYEV, M., - ORAZBAYEV, A., Drevnyaya kultura Tsentralnogo Kazahstana, Alma-Ata, 1966, s. 207

MARGULAN, Alkey - BASENOV, T. - MENDIKULOV, M., Arhitektura Kazahstana, AlmaAta, 1959.

MARGULAN, Alkey - BASENOV, T. - MENDIKULOV, M., Kazakstan Arhitekturası, Cilt 1, Öner baspas1, Almat1, 2010.

MARSHAK, Boris Iliç, "The Ceilings of the Varakhsha Palace" Parthica 2. Incontri di culture nel mondo antico. Istituti editoriali e poligrafici internazionali, Pisa-Rome, 2000, s. 153167.

NAURIZBAYEVA, A., Sintez predmetno-prostranstvennoy sredl:prikladnoya isskustvo i jiloy interyer $v$ istorri Kazahstana, Kazahskaya natsionalnaya akademiya isskustv im. T. Jurgenova, Almat1, 2018.

ORAZBAYEV, A., Poseleniye Çaglinka (Şagalalı), Nekotorye formy i tipı jiliş, Po sledam drevnih kultur Kazahstana, Nauka, Alma-Ata, 1970, s. 129-146.

OUTRAM, A.K. - STEAR, N.A. - BENDREY, R. - OLSEN, S. - KASPAROV, A. - ZAIBBERT, Viktor - THORPE, N. - EVERSHED, R.P., "The earliest horse harnessing and milking", Science, Cilt 323, Say1 5919, 2009, s. 1332-1335.

POPOV, A., Jilişe, İstoriko-etnografiçeskiy atlas Sibiri, Moskva-Leningrad, 1961.

POTAPOV, L., Oçerki po istorii Altaytsev, OGİZ, Novosibirsk, 1948.

REŞETNIKOV, A.- GUDKOV, A., Vliyaniye russkoy stroitelnoy kultur na traditsionnuyu arhitekturu naroda Saha v XVII-XVIII vv., Vestnik TGASU, 2019.

ROGOZHINSKY, Alexei, Novie nahodki pamyatnikov Drevnetyurkskoy epigrafiki i monumentalnogo iskusstva na Yuge i Vostoke Kazahstana. Rol nomadov v formirovanii kulturnogo naslediya Kazahstana, Nauçnıe çteniye pamyati N. Masanova, Almat1, 2010, s. 329-344.

RUDENKO, Sergei, "Kultura naseleniya Gornogo Altaya v skifskoye vremya", Izdatelstvo AN SSSR, Moskva, Leningrad, 1953, s. 79

SALNIKOV, K., "Bronzovyi Vek Yujnogo Zauralya", MİA,Moskva, 1951,Cilt 2, s. 94-152

SMAGULOV, E., "Kompleks ritualnıh atributov iz Otrarskogo oazisa", Arheologiçeskiye issledovaniya $v$ Kazahstane, Alma-Ata, 1992, s. 34-42

SÖZEN, Metin - TANYELİ, Uğur, Sanat Kavram ve Terimleri Sözlü̆̆̈̈, Remzi Kitabevi, İstanbul, 2003.

Şiş̧İN, V., Varahşa, İzdatelstvo Akademii Nauk SSSR, Moskva, 1963.

TOLSTOV, S. , Po Drevnim deltam Oksa i Yaksarta , Moskva, 1962.

TORGOYEV, A., "K datirovke meçeti v Taraz"e, İzestiye Natsionalnoy Akademii Respubliki Kazahstan, 2013, Sayı 3, s. 127-132. 
Orta Asya'da Tütekli (Kırlangıç) Örtünün Kökeni ve Tarihî Gelişim Aşamaları Üzerine bir Değerlendirme

VOLIÇENKO, O. - ALMAGANBETOVA, K., "Arhitektura Dvortsa-Tsitedeli”, Aktualnye problemı gumanitarnıh i estesstvennıh nauk, Say1 1(84) Ocak, 2016, s.114-118.

ZAİBERT, Viktor, Eneolit Uralo-Irtışskogo mejdurechya, Nauka, Pertopavlovsk, 1993.

ZAİBERT, Viktor, Botayskaya kultura, KazAkparat, Almat1, 2009,

ZAİBERT, Viktor, "Botaiskaya kultura- Matrisa Stepnoy Tsivilizatsii”, Margulan Okuları 2019, Körnekti kazakstandık arheolog K.A.Akişevtin 95 juldlgına arnalgan Halıkaralık arheologiyalık gllımi-tajribelik konferentsiya materialdarl, Nur-Sultan, 2019.s. 108-111.

ZHOLDASBAYEV, S., Kazak Elinin XV-XVIII gastrlardagı turaktı mekencayları, Kazak g1lımi-zertteu institutının baspa tobı, Astana, 2017.

\section{İnternet Kaynakları}

https://kgcode.akipress.org/unews/un_post:8210 (E. T: 20.08.2020)

http://russights.ru/post 1425239264.html (E. T: 25.08.2020)

http://xn--80aakae1am0d.xn--p1ai/photogallery/822/4853 (E.T: 20.08.2020)

https://www.yakutskhistory.net/ (E.T: 20.08.2020)

Volume 12

Issue 5

October

2020 